\title{
FAMILY BUSINESS GROWTH AROUND THE WORLD
}

\begin{abstract}
Growth is important for the long-term success of a business. Regrettably, the impact of family influence on firm growth is largely neglected. We examine whether family firms have a higher growth rate than their non-family counterparts. Based on a large sample of firms across 43 countries over a 10-year period, we show that family firms on average have higher growth rates than non-family firms, and this positive effect is greater for family firms operating in strong national institutional environments which are less corrupt, more democratic, more subject to rule of law, and have effective government policies. We also find that the positive effect of family influence on firm growth varies significantly across different types of family firms and different business cycles. These findings have important implications for theory and practice.

\section{KEYWORDS}

family firm growth, institutional context, long-term orientation, family business 


\section{INTRODUCTION}

Financial returns and revenue growth are important aspects of firm success (Davidson, Delmar, \& Wiklund, 2006). The former have been well-studied by scholars of family business in dozens of articles and several meta-analyses (Anderson \& Reeb, 2003a; Chen, Hou, Li, Wilson, \& Wu, 2014; Miller, Le Breton-Miller, Lester, \& Cannella, 2007; Wagner, Block, Miller, Schwens, \& Xi, 2015). However, the literature on family firm growth is far less developed. According to a survey of over 300 variables examined in empirical family business studies (Yu, Lumpkin, Sorenson, \& Brigham, 2012), growth has been very much neglected, and indeterminate as to its relationship with family influence (Evert, Martin, McLeod, \& Payne, 2016). The common theoretical view is that family influence changes the strategic behavior of the family firm (Chua, Chrisman, \& Sharma, 1999), thereby affecting its growth. However, the nature and magnitude of this influence remains unclear: specifically, whether family firms grow faster or slower than their non-family counterparts remains unknown. Empirical evidence on the topic would not only enrich our knowledge of family business behavior but also improve policy options.

In fact, vying perspectives of family firms surface conflicting views of family firm growth. One suggests that such firms will grow more slowly due to principal-principal agency costs ("the agency view"), as family members use their publicly traded firms for private benefit (Le BretonMiller \& Miller, 2018; Pérez-González, 2006; Villalonga \& Amit, 2006). This position is consistent with much of the literature on socioemotional wealth (Gómez-Mejía et al., 2014; Gómez-Mejía, Haynes, Nunez-Nickel, Jacobson, \& Moyano-Fuentes, 2007). In sharp contrast, "the long-term orientation view" suggests that families will invest generously in their firm and its growth due to the long-run benefits that will bring to their offspring, the firm, and its stakeholders (Arregle, Hitt, Sirmon, \& Very, 2007; Eddleston \& Kellermanns, 2007; Miller, Le Breton-Miller, 
\& Scholnick, 2008).

To shed light on family firm growth, we analyze the growth rates of 5,265 publicly traded firms from 43 countries in 33 industrial sectors from 2007 to 2016. Specifically, we examine whether family firms grow more - the long-term view, or less - the short-term agency view, than nonfamily firms, and also identify the institutional country-level governance indicators under which family firms can achieve superior growth. To that end, we develop a model of family firm growth and test it across different institutional environments. In so doing, we construct absolute and relative firm growth proxies using net sales and total assets to account for the diversity in growth measurements. We also adopt an overall index of country-level governance based on indicators from the World Bank, along with individual dimensions of this index to capture the heterogeneity of institutional environments around the world. To mitigate endogeneity and sample selection bias we exploit the longitudinal nature of our data and employ panel data and 2SLS estimators. We also examine variations of the family business effect on firm growth across different types of family firms, industries and over business cycles. In addition, a battery of robustness tests is performed to rule out possible alternative explanations for our findings.

We find that on average family firms exhibit a higher growth rate than non-family firms, thus supporting the long-term view. Moreover, a positive country-level institutional environment of democratic freedom, government effectiveness, corruption control and political stability significantly increases the positive effect of family influence on family firm growth. A family's long-term perspective of its business and the superior growth funded by that orientation flourishes in positive institutional environments with less uncertainty that enables family economic and socioemotional priorities to be realized via the long-term performance of the business.

Furthermore, we find that the positive family business effect on firm growth applies mostly 
to first-generation firms, regardless of whether the CEO is family member or not, as compared to non-family firms and later-generation family firms. Later-generation family firms can achieve above-average growth rates only if they have a professional CEO and operate in countries with good institutional environments. As to variations across industries, we do not find that industry context plays an important role. In particular, the positive effect of family influence on firm growth is present in both industries with low and high levels of market concentration. Finally, we document that the positive effect of family influence on firm growth does not hold in times of financial crisis for firms operating in countries with weak institutional environments.

This paper contributes to the literature in several ways. First, most studies have analyzed the financial returns of family firms. Growth is a key concern given the common view that family firms sacrifice growth in favor of family influence - a basis for much of the theorizing on this type of organization (Berrone, Cruz, \& Gomez-Mejia, 2012). The few studies of growth are crosssectional (Campopiano, Brumana, Minola, \& Cassia, 2019; Lee, 2006; McConaughy \& Phillips, 1999), and have focused mainly on small and medium-sized entrepreneurial firms (Chen et al., 2014; Chrisman, Chua, \& Litz, 2004). We arbitrate between and condition the application of key conceptual perspectives of family firms - principal-principal agency theory and the long-term orientation perspective (Miller \& Le Breton-Miller, 2005 2014; Lumpkin \& Brigham, 2011). To the best of our knowledge, this is the first longitudinal study supporting the long-term view of family business growth, employing panel data and instrumental variables (IV) estimators along with alternative variable definitions and a variety of control variables. In so doing, it opens an agenda for future research on the growth of firms with concentrated ownership.

Second, we identify institutional conditions around the world leading to the extraordinary growth of family firms. Where democracy, effective government, the rule of law and political 
stability prevail, investing in the growth of the family firm is better able to achieve long-run economic and socioemotional family objectives than where institutional uncertainty abounds, and where extraction of private benefits is a superior family option, which in turn can retard firm growth (Amit, Ding, Villalonga, \& Zhang, 2015; Peng \& Jiang, 2010; Soleimanof, Rutherford, \& Webb, 2017). Thus, our study reveals that the magnitude of the relationship between family influence and firm growth is dependent upon the institutional context, thereby bridging the family business growth literature with that on political and economic institutions. It also identifies variations of family business growth across different types of family firms, countries and business cycles, providing a novel understanding of the complexity of family business growth.

In the remainder of the paper we first present our theoretical arguments and hypotheses. Then, we describe our data and methods. Next, we discuss our main findings along with the results of post-hoc analyses and robustness checks. After that, we draw theoretical, managerial and policy implications from our study, also discussing limitations and future research avenues.

\section{THEORY AND HYPOTHESES: AGENCY VS. LONG-TERM PERSPECTIVES}

We present two opposing sets of arguments concerning the growth of family firms drawn from two popular perspectives - namely agency and long-term orientation perspectives. We also reference the socioemotional wealth perspective as it surfaces mostly negative and sometimes positive aspects of family firms that tie in with both principal-principal agency and long-term orientation views (Miller \& Le Breton-Miller, 2014).

\subsection{Stunted Growth: The Short-term, Principal-Principal Agency Perspective}

Although traditional agency theory posits low agency costs for owner-run businesses such as 
family firms (Fama \& Jensen, 1983), many studies suggest that these firms experience significant principal-principal agency costs, as family members, particularly in publicly traded firms, appropriate private benefits from the business (Chrisman et al., 2004; Muñoz-Bullón \& SanchezBueno, 2011; Villalonga \& Amit, 2006). This appropriation limits the resources available to the family firm to fund growth initiatives.

Bertrand and Schoar (2006) and Pérez-González (2006) suggest that private benefits may take the form of nepotism, favoritism, and entrenchment such that incompetent executives remain in their position despite poor results. Bloom and Van Reenen (2007) agree, finding that compared to family firms, non-family firms are more likely to adopt modern management techniques to be more efficient and innovative. Also, family firms are said to employ less sophisticated financial management techniques, except when they have an outside director or a non-family member involved in financial decision-making (Filbeck \& Lee, 2000).

Consistent with that view, the socioemotional wealth (SEW) perspective argues that family firm owners will act to preserve their SEW endowment and resist taking risks that may jeopardize that (Gómez-Mejía et al., 2013; Gómez-Mejía et al., 2007; Kotlar, Signori, De Massis, \& Vismara, 2018). Thus, they may ignore new business opportunities and innovate less if this threatens family control (Block, 2012; Gómez-Mejía, Makri, \& Kintana, 2010; Patel \& Chrisman, 2014). It has also been argued that family firms can lack effective management because family top executives are drawn from a smaller talent pool than in non-family firms (Bertrand \& Schoar, 2006; Mehrotra, Morck, Shim, \& Wiwattanakantang, 2013; Miller, Xu, \& Mehrotra, 2014). Such executives may not have the skills to successfully orchestrate growth strategies.

Another growth resource that may be scarcer in family firms is capital. If family members wish to retain control of their firms, they will be less likely to incur debt (Mishra \& McConaughy, 
1999; Molly, Uhlaner, De Massis, \& Laveren, in press), or to issue shares that dilute their control (Villalonga \& Amit, 2009; Wu, Chua, \& Chrisman, 2007). Finally, family members may differ in their priorities (Kotlar \& De Massis, 2013), resulting in conflicts that drain the firm of resources required for growth.

\subsection{Superior Growth: The Long-Term Perspective}

The long-term perspective presents an opposite point of view of the growth potential of family firms (Miller \& Le Breton-Miller, 2005; 2014). In reviewing the literature, Villalonga, Amit, Trujillo, and Guzmán (2015) highlight several studies that employ the long-term perspective (Block \& Henkel, 2010; Brigham, Lumpkin, Payne, \& Zachary, 2013; Lumpkin \& Brigham Keith, 2011) to understand family firms. Kappes and Schmid (2013) suggest that family firm managers have long time horizons for their business because they wish to preserve it for the family and its later generations. They avoid short-term expedients to grow profits and generously invest in the future of their companies. In other words, they promote conditions favoring long-term growth over short-term profits, thereby avoiding a "quarterly earnings mentality".

As the family legacy and the well-being of subsequent generations may be tied to the robustness of the business, some family members are keen to ensure firm continuity. They may do so by investing in the future of the business, strengthening relationships with employees via assiduous training and superior working conditions (De Massis, Audretsch, Uhlaner \& Kammerlander, 2018; Reid, Dunn, Cromie, \& Adams, 1999), and building long-term, flexible relational connections with outside stakeholders such as suppliers and customers (Orth \& Green, 2009). They also may generously invest in renewing the business via new product offerings and market extensions (Miller, Le Breton-Miller, \& Lester, 2007). 
Assiduous pursuit of a long-term orientation also leads to the accumulation of unique resources. Habbershon and Williams (1999) highlight access to family financial capital, cheap and loyal family labor, a motivated and stable management team, and social capital in the form of relationships with the community, including government institutions (Arregle et al., 2007). Due to their concern for the family's reputation, some family firms also have an incentive to promote and sustain family-branded products (Craig, Dibrell, \& Davis, 2008). In addition, in view of the relative stability and authority of family governance, family firms can form enduring relationships with other family businesses to promote joint commercial interests (Le Breton-Miller, Miller, \& Lester, 2010; Miller \& Le Breton-Miller, 2005; Salvato \& Melin, 2008). And thanks to their discretion and independence from short-term pressures from public shareholders (Ali, Chen, \& Radhakrishnan, 2007), family executives are able to make bold decisions to adapt to new conditions when the environment changes or when important new growth opportunities arise (Zahra, Hayton, \& Salvato, 2004). Finally, given their extended investment horizons (Kappes \& Schmid, 2013), owners are more likely to eschew opportunism (Blair \& Stout, 2006) to embrace a more growth oriented culture.

\subsection{Stunted growth vs. Superior growth}

Clearly, the principal-principal agency and long-term views lead to opposite conclusions regarding family firm growth. And the empirical findings to date do not help to resolve this debate. For example whereas the cross-sectional analysis of S\&P 500 firms by Lee (2006) reveals that family firms on average exhibit higher growth rates than non-family firms, larger cross-sectional studies of family firms from 35 countries by Campopiano et al. (2019) and of entrepreneurial firms from 80 countries by Chen et al. (2014) report a negative effect of family influence. In other words, "the 
jury is still out". That being said, the firm growth literature suggests that high growth is largely a result of long-term investments in innovation and enduring relationships with employees, clients, suppliers, or the community (Del Monte \& Papagni, 2003; García-Manjón \& Romero-Merino, 2012; Unger, Rauch, Frese, \& Rosenbusch, 2011). Firms that consistently invest in innovation experience higher growth by introducing new products, services and business models (Geroski \& Machin, 1992; Yasuda, 2005). Similarly, people-related investments boost employee motivation, engagement and productivity (Bakker \& Schaufeli, 2008; Oswald, Proto, \& Sgroi, 2015) and create strong organizational identities (Dorrenbacher, Tomenendal, \& Stanske, 2017), thereby boosting growth (Goedhuys \& Sleuwaegen, 2016; Grover Goswami, Medvedev, \& Olafsen, 2019).

Family firms are also said by some to excel in such long-term investments in innovation vis-a-vis non-family firms (Bergfeld \& Weber, 2011; Kappes \& Schmid, 2013). Moreover, they may produce more innovation output than others (De Massis, Frattini, Pizzurno, \& Cassia, 2015; Duran, Kammerlander, Van Essen, \& Zellweger, 2016). Family firms also invest more in human capital in the form of union relations, employee involvement and protection, retirement benefits, cash profit sharing, health and safety than non-family firms (Kang \& Kim, 2019; Sanchez - Bueno,

Muñoz - Bullón, \& Galan, 2019). Moreover, they are known for investing in superior relationships with clients, suppliers and community (Baù, Chirico, Pittino, Backman, \& Klaesson, 2018; Lamb \& Butler, 2016; Le Breton-Miller et al., 2010). Thus, we argue that many family firms, thanks to their long-term orientation regarding superior innovation- and employee-related investments, are more likely to achieve a higher growth rate than their non-family counterparts.

Hypothesis 1 (H1): Family firms exhibit a higher growth rate than non-family firms.

\subsection{The role of institutional environments}


Whereas $\mathrm{H} 1$ predicts a positive impact of family influence on firm growth, the institutional environment may have an important moderating effect. This is in line with prior research that has emphasized the theoretical and practical importance of institutional environments for family firm decision-making processes (Ahuja, Capron, Lenox, \& Yao, 2018; Banalieva, Eddleston, \& Zellweger, 2014; North, 1990; Peng \& Jiang, 2010).

Specific conditions in the macro institutional environment may contribute to family firm growth. Country-level governance dimensions such as democratic freedom, government effectiveness, regulatory quality, rule of law, corruption control and political stability may have a profound effect on family firm growth - a core distinguishing priority of family firms (e.g. Miller \& Le Breton-Miller, 2005; Lumpkin \& Brigham, 2011) - because they influence the degree to which family owners and executives can embrace their natural long-term orientation toward their companies. Specifically, we shall argue that in the normal course, families want their companies to serve as vehicles for the long-term economic, vocational and social benefits of family members. This will induce them to invest generously in their business, its people and its products to build a promising future for the family inside the business (Kappes \& Schmid, 2013; Miller \& Le BretonMiller, 2005). That can augur well for extraordinary family firm growth and give them a natural advantage over their non-family counterparts. However, where democratic institutions, government effectiveness, the rule of law, and political conditions are weak, an uncertain environment prevails. This makes it less possible for families to follow their natural long-term orientation for their business, which faces abundant risks within such contexts (Kao, 1993). Instead, they are more likely to fulfill family objectives by taking resources out of the business, tunneling, and building a family nest-egg separate from their companies (Morck \& Yeung, 2003; Morck \& Yeung, 2004), thereby decreasing the growth rate of family firms. 
In the discussion that follows, we propose the effects of each of these country-level governance dimensions.

Democratic Institutions: Democratic countries around the world experience more economic growth in part by encouraging investment, fostering economic vitality, and avoiding social unrest. According to Acemoğlu, Naidu, Restepo, and Robinson's (in press) analysis of 175 countries over 50 years, democracy increases GDP per capita by about 20 percent. Similarly, Papaioannou and Siourounis (2008) find a significant positive effect of democratization on annual per capita growth. In a democratic economy, family firms are likely to have the confidence to invest generously in growing their businesses, particularly given their long-term perspective of ensuring a promising future for offspring and a developing family (Le Breton-Miller \& Miller, 2006; Miller, Le Breton-Miller, \& Lester, 2007). In other words, unless family firms are dissuaded by adverse political conditions, they will tend to invest more than their non-family counterparts in firm growth and renewal (Miller et al., 2008). By contrast, where economies are less democratic, the resulting uncertainty of long-term investment in the business may induce family owners and executives to take money out of their companies in order to secure the financial future of the family - perhaps by extracting private benefits (Morck, Wolfenzon, \& Yeung, 2005). Diversifying personal wealth, perhaps even by taking funds out of the country, will be seen as a superior option (Harrington, 2016), thereby retarding the growth of the family firm.

Government Effectiveness: Another important feature of the country-level institutional context is government effectiveness. There are major international variations in the effectiveness of governmental fiscal and social policies, which can either enhance or obstruct relationships between the state, corporations, and other stakeholders (Aguilera \& Jackson, 2003). Countries with more effective civic and economic policies, and long-term government policy commitments, are 
more likely to induce families to invest in their companies (Crouzet, 1999). Again, given the longterm orientation of family firm owners and managers, propitious institutional conditions will induce them to invest in a business to which a family's economic, career, and social futures are attached (Kappes \& Schmid, 2013; Miller et al., 2008). Indeed, such long term orientation enables family firms to build trust-based and stable networks (De Massis et al., 2018; Gudmundson, Hartman, \& Tower, 2004), which may lead to enduring long-term relationships with far-sighted and effective governments.

Regulatory Policy and Rule of Law. A vast literature establishes that countries vary greatly in their ability to pass sound laws and guarantee shareholder protection (La Porta, Lopezde-Silanes, \& Shleifer, 2013). An analysis of 39 countries by Dyck and Zingales (2004) finds that country-level institutions such as protection of minority shareholders and better law enforcement reduce the private benefits of control. A strong legal environment limits family firm owners' ability to extract private benefits and expropriate minority shareholders, making investment in the firm more likely (Gale \& Scholz, 1994). Indeed, the negative effects on firm value of having a family CEO in Asian listed companies were mitigated by effective national legal and regulatory institutions (Peng \& Jiang, 2010).

Furthermore, countries with better legal environments have more developed capital markets (La Porta, Lopez-de-Silanes, Shleifer, \& Vishny, 2000) and financial intermediaries (Levine, Loayza, \& Beck, 2000) because they promote better monitoring and reduce information asymmetries between managers and investors (Dittmar, Mahrt-Smith, \& Servaes, 2003; Giannetti, 2003). In such contexts, family firms will be more able to pursue their natural inclination towards superior growth.

Freedom from Corruption: Corporations often must negotiate, lobby, and interact with 
public officials to access resources and ensure a positive economic environment. When there is corruption in a country, there is more opportunity for public officials and firms to engage in nefarious bribes and embezzlement. According to Krueger (1974) and Murphy, Shleifer, and Vishny (1993), such corruption diverts financial resources away from investments in physical assets, innovation, and expansion, into the pockets of rent-seeking politicians and perhaps those of owning families' personal finances rather than their firms. This hampers economic and company growth (Kaufmann, Kraay, \& Mastruzzi, 2011).

Studies have shown that family firms are more socially responsible and ethical than their non-family counterparts (Berrone, Cruz, Gomez-Mejia, \& Larraza-Kintana, 2010; Dyer \& Whetten David, 2006; O'Boyle, Rutherford, \& Pollack, 2010), in part because they wish to preserve a positive family image and reputation across generations (Cennamo, Berrone, Cruz, \& Gomez-Mejia, 2012; Craig et al., 2008). Again, this is consistent with the long-term orientation of many family firms. In a corrupt environment, such ethical family firms may struggle to obtain the resources needed to grow in the face of rent-seeking public officials, or benefit from corruption by extracting private benefits (Kao, 1993) thereby decreasing their growth rate. In a less corrupt country, family firms are freed from such resource constraints and, thus, can access more resources and speed the growth they value for the long-term success of the family and its generations.

Political Stability and Absence of Terrorism: Political stability is an important prerequisite of the well-functioning business society (Peng, Sun, Pinkham, \& Chen, 2009). Given that longestablished family firms have prospered in Europe (Barontini \& Caprio, 2006), Asia (Chen, Firth, Gao, \& Rui, 2006), the U.S. (La Porta, Lopez-De-Silanes, \& Shleifer, 1999) and elsewhere, and often have strong connections with local governments (Ciravegna, Kano, Rattalino, \& Verbeke, 2019), political instability or violence can hamper their growth. According to European Family 
Business and KPMG (2016), political instability is frequently mentioned by family firms as one of their biggest challenges for growth. There is also evidence that given their long-term orientation, some family firms find it hard to re-establish connections with new governmental authorities when there are sudden shifts in political power (Leuz \& Oberholzer-Gee, 2006). Therefore, in unstable political contexts family firms may be less able to pursue their ambitious growth objectives.

To summarize, countries with democratic institutions, government effectiveness, the rule of law and political stability can be said to benefit from strong, that is stable and promising, political and economic environments. There, the long-term orientation of many family firms will induce them to invest in their companies to achieve superior growth. Conversely, they are likely to grow more slowly in unstable institutional environments, where politics and economics are uncertain, costs of doing business are high, and where it is safer for family owners to extract private benefits rather than invest in their companies' growth. Therefore:

Hypothesis 2 (H2): The positive effect of family influence on firm growth will be greater in countries with strong institutional environments than in countries with weak institutional environments.

\section{DATA}

\subsection{Sample}

To examine the relationship between family influence and firm growth, we constructed a worldwide sample of publicly traded firms. We employ the NRG Metrics database's Family Firms dataset. This dataset is created by a team of expert analysts who manually enter, review, and cross check data with senior analysts, who perform frequent random audits. NRG Metrics sources publicly available documents such as annual reports, corporate governance reports, firm presentations, SEC filings, and press releases. Customized software programs verify all levels of 
data entry for inconsistencies and errors using a combination of quality control measures (NRG documents).

The dataset covers 7,000 publicly-traded (active and non-active) firms from America, Europe, Asia and Africa beginning in fiscal year 2007. All financial firms were excluded following common practice (Barontini \& Bozzi, 2018). We collected financial and accounting firm-level data from Thomson-Reuters Datastream. Country-level macroeconomic data were taken from the World Bank (see below). In total, our final sample comprises 5,265 publicly-traded manufacturing and non-manufacturing firms from 43 countries covering the period 2007 to 2016, inclusive.

Three types of publicly traded companies are present in our dataset: 1) companies in the dataset for the entire period of analysis (51.62\%); 2) companies that enter the sample during the period $(36.14 \%)$; 3 ) companies that exit during the period (12.24\%) because they become privately held, merged, liquidated or inactive. This data structure enables us to mitigate survivorship bias (Elton, Gruber, \& Blake, 1996).

Tables 1 shows the composition of our sample by family control and industry. The largest portion of publicly traded firms in our sample cover Anglo-Saxon (Australia, Canada, UK, US and New Zealand) and European countries, amounting to $43 \%$ and $39 \%$ of the sample. Asian countries represent $12.5 \%$ of the sample, and $5.5 \%$ are other countries. The largest fraction of family firms, $22 \%$, come from the US.

\section{INSERT TABLES 1 AND 2 HERE}

Tables 2 shows the composition of our sample by family control and industrial sector (three-digit ICB codes). Over half of the sample are in industrial, consumer goods and consumer services sectors (57\%), while the rest fall into the basic materials, health care, oil and gas, technology and communications and utilities sectors. Family control is a common characteristic 
of firms belonging to a broad array of manufacturing industries in our sample, the average is around $33 \%$ of all firms. We observe the most family firms in industrials, consumer goods and services (around 27\%, 18\% and 18\%, respectively) and the fewest in utilities and telecommunications $(1.79 \%$ and $1.66 \%$, respectively).

\subsection{Measures}

\subsubsection{Dependent variable}

Several measures of firm growth appear in the literature: sales, total assets, profitability ratio, employment, and value added (Audretsch, Coad, \& Segarra, 2014; Reuber \& Fischer, 2002). Davidson et al. (2006) argue that sales growth is the more appropriate proxy of firm growth as it is less subject to accounting manipulations and short-term market reactions. We measure firm growth as the log-difference of net sales for company $i$ from country $c$ between time $t$ and $t-1$ (García-Manjón \& Romero-Merino, 2012; Rahaman, 2011). Adoption of the two-year and threeyear firm growth rates did not alter our results.

\subsubsection{Independent variables}

Many studies operationalize a family firm by the ownership stake of the controlling family (Anderson \& Reeb, 2003a; Barontini \& Caprio, 2006; Faccio \& Lang, 2002; La Porta et al., 1999). Others use family management (Sciascia, Mazzola, \& Chirico, 2013; Zahra, Neubaum, \& Larrañeta, 2007). And still others require a substantial ownership stake and as well as managerial presence (Chrisman \& Patel, 2012; Chua et al., 1999; Kotlar, Fang, De Massis, \& Frattini, 2014; Kotlar et al., 2018). Accordingly, our Family variable captures fractional equity ownership of the founding family and/or the presence of family members serving on the board of directors. It is 
coded as a dummy that equals 1 if a founder, descendant or family member is a director or large shareholder (Anderson \& Reeb, 2003a, 2003b) ${ }^{i}$. Family firms represent around 33\% of our sample, which is in line with prior studies of listed firms (Anderson \& Reeb, 2003a; Villalonga \& Amit, 2006).

To assess country-level institutional environments, we adopted the World Governance Indicators (WGIs) that capture the process by which governments are selected, monitored, and replaced, government capacity to effectively formulate and implement sound policies, and the respect of citizens and the state for the institutions that govern their economic and social interactions. Specifically, we focused on the following WGIs in this study: Democratic freedom, Government effectiveness, Regulatory quality, Rule of law, Corruption control, Political stability and Absence of terrorism (Political Stability) (see Table 3 for details). These indicators are based on over 30 individual data sources produced by a variety of survey institutes, think tanks, NGOs, international organizations, and private sector firms (Kaufmann et al., 2011). These WGIs have been validated in prior literature by both management (Chen et al., 2014) and corporate governance scholars (Ding, Qu, \& Wu, 2016).

\section{INSERT TABLE 3 HERE}

Individual WGIs exhibit relatively high correlations (ranging from 0.67 to 0.96), suggesting that even though these dimensions reflect different dimensions of the country-level institutional environment, they are highly correlated. Therefore, we used Principal Component Analysis (PCA) to derive an overall WGI proxy of the institutional environment. Specifically, the PCA produced a linear combination of all the components of WGI with the highest variance. The factors in our analysis all have an eigenvalue greater than one. 


\subsubsection{Control variables}

We controlled for both micro-level variables (financial leverage ratio, cash flow ratio, R\&D, firm age and firm size) and macro-level variables (GDP growth, trade, and inflation) in our explanatory model. Following prior studies (Huynh \& Petrunia, 2010), Financial leverage is included as a measure of debt, and Cash flow reflects internal finances (Brown \& Petersen, 2009). We calculated financial leverage as total debt to total assets, and cash flow as net income and non-cash charges to total assets (Testa, Miroshnychenko, Barontini, \& Frey, 2018). $R \& D$ was computed as R\&D expenses to net sales to proxy for innovation (Audretsch et al., 2014). As missing R\&D observations are common (Koh \& Reeb, 2015), this data existed for only 34\% of our sample; thus following O’Connor and Rafferty (2012), all missing R\&D values were scored as zero.

Numerous studies suggest that larger and older companies grow more slowly than their smaller and younger counterparts (Hardwick \& Adams, 2002; Oliveira \& Fortunato, 2006; Yasuda, 2005). Therefore, following Hardwick and Adams (2002); Huynh and Petrunia (2010) Firm size (logarithm of total assets) and Firm age (logarithm of numbers of years the firm exist) are added to our explanatory model. Moreover, as firms grow faster in open and expanding economies (Acemoğlu et al., in press; Beck, Demirguc-Kunt, Laeven, \& Levine, 2008), we controlled for GDP growth (calculated as the annual percentage growth rate of real GDP) ${ }^{\mathrm{ii}}$ and Trade proxies (calculated as the sum of exports and imports of goods and services of a country as a share of GDP) (Allen, Qian, \& Qian, 2005). We also incorporated the Inflation rate to control for price dynamics (Apergis, 2004), and industry (three-digit ICB codes) and year dummies to account for industrial differences and business cycles (Bozzi, Barontini, \& Miroshnychenko, 2017). It is important to note that firm-level fixed effects could not be employed as family firm status rarely changed during our period of analysis (Dyer \& Whetten David, 2006; Villalonga \& Amit, 2006). 


\section{ESTIMATION STRATEGY}

\subsection{Empirical model}

The explanatory model used to examine the impact of family influence on firm growth is as follows:

$$
\text { Growth }_{i c, t}=\beta_{0}+\beta_{1}\left(\text { Family }_{i c, t}\right)+\beta_{2}\left(\text { Controls }_{i c, t}\right)+i_{i}+d_{t}+\varepsilon_{i c, t}(1)
$$

where $i$ refers to firms, $c$ refers to countries, $t$ refers to years, Family $y_{i c, t}$ represents proxy of family influence, Controls $_{i c, t}$ is a vector of control variables (Firm size ${ }_{i c, t}$, Firm age $_{i c, t}, R_{\&} D_{i c, t}$, Financial leverage $_{i,, t}$, Cash flow $_{i c, t}$, GDP growth $_{c, t}$, Trade $_{c, t}$, Inflation $\left._{c, t}\right), i_{i}$ stands for industry fixed effects (three-digit ICB codes), $d_{t}$ represents year fixed effects, and $\varepsilon_{i c, t}$ is an error term.

To check the moderating effect of the $W G I_{c, t}$ on the association between family influence and firm growth, we added the $W G I_{c, t}$ and its interaction term with Family ic, $_{\text {t }}$ to our equation (1). $W G I_{\mathrm{c}, \mathrm{t}}$ was mean-centered in the interaction to increase interpretability of estimates (Afshartous \& Preston, 2011). Thus, our basic model (1) can be re-written as:

Growth $_{i c, t}=\beta_{0}+\beta_{1}\left(\right.$ Family $\left._{i c, t}\right)+\beta_{2}\left(W G I_{c, t}\right)+\beta_{3}\left(\right.$ Family $\left._{i c, t} x W G I_{c, t}\right)+\beta_{4}\left(\right.$ Controls $\left._{i c, t}\right)+i_{i}+d_{t}+\varepsilon_{i c, t}(2)$

where the coefficient of $W G I_{c, t}$ captures the effect of average country-level institutional environment on firm growth for the reference group (non-family firms). The Family $y_{i c, t}$ dummy reflects the family business effect on firm growth for firms operating in countries with average country-level institutional environment. The interaction term Family $_{i c} x W G I_{c, t}$ shows how family business growth varies as the average country-level institutional environment improves.

The results of the Durbin-Watson and Wu-Hausman tests show that Firm size $i c, t, R \& D_{i c, t}$ and Cash flowic, variables from our explanatory model did not meet the exogeneity assumption ${ }^{\text {iii }}$. To address this problem, we adopted a two-stage least squares (2SLS) estimator (Rose \& Stone, 2011). In the first stage, we regress the endogenous variables (Firm size $i c, t, R \& D_{i c, t}$ and Cash 
flow $_{i c, t}$ ) on all the exogenous variables $\left(\right.$ Family $_{i c, t}$, Financial leverage $_{i c, t}$, GDP growth $_{c, t}$, Trade $_{c, t}$, Inflation $_{c, t}$, Industry and Time dummies) and the instrumented variables (IVs) to remove the proportion of these variables correlated with the error term. Due to an absence of strong external IVs in the literature, we adopted first- and second-year lagged values of Cash Flowic,t and secondyear lagged values of Firm size $e_{i c, t}$ and $R \& D_{i c, t}($ Krafft, Qu, Quatraro, \& Ravix, 2013). In the second stage, the predicted values of the endogenous variables are used to estimate the explanatory variables (Firm size ic,t, $R \& D_{i c, t}$ and Cash flowic,t). To confirm the strength of our IVs (their correlation with endogenous regressors) and their validity (their orthogonality to the error term), we conducted both Kleibergen-Paap and Hansen tests. All the 2SLS regressions were estimated using the ivreg2 command in Stata (Baum, Schaffer, \& Stillman, 2003) (see Table 8).

We used robust standard errors clustered at the firm level to relax homoscedasticity and autocorrelation assumptions Petersen (2009). In addition, to test the joint significance of the reported coefficients, industry dummies, and year dummies, we employed three Wald tests using the testparm command in Stata.

\subsection{Descriptive statistics, univariate tests and correlation matrix}

Table 4 displays descriptive statistics. Our firms exhibit significant variability in growth rates, averaging 0.047 , with standard deviation 0.336 . Institutional development also varies substantially across countries, as shown in Table 5. Finland, Denmark and Sweden enjoy the best institutional environment, while Russia, Indonesia and the Philippines have the worst.

\section{INSERT TABLES 4 AND 5 HERE}

Univariate analyses displayed in Panel A of Table 6 shows that family firms exhibit a higher annual growth rate than their non-family counterparts $(\mathrm{p}<0.001)$. This result also holds for two- and three-year growth rates $(\mathrm{p}<0.001)$, suggesting that family firm superior growth persists 
for years.

Panel B of Table 6 shows growth rates by geography. Family firms from Anglo-Saxon or Asian countries - leading economic superpowers - have higher growth rates than non-family firms $(\mathrm{p}<0.001)$. Also family firms from Asian countries, including the "Asian Tigers" of Singapore, Hong-Kong and South Korea, have significantly higher growth rates over one- $(\mathrm{p}<0.001)$, two$(\mathrm{p}<0.001)$ and three-year periods $(\mathrm{p}<0.001)$ than family firms from Anglo-Saxon countries, likely due to the extraordinary growth of the Asian economies (Fontana \& Srivastava, 2009; Gulati, 1992).

\section{INSERT TABLES 6 AND 7 HERE}

Table 7 presents the correlation matrix. We find that family firm status and firm growth are positively correlated $(\mathrm{p}<0.001)$. Also, firm growth is negatively correlated with firm size, firm age and financial leverage $(\mathrm{p}<0.001)$, while cash flow is positively correlated with firm growth ( $\mathrm{p}<0.001)$. Variance inflation factors (VIF) were never exceeded 4 (O'Brien, 2007), suggesting that multicollinearity was not a concern.

\section{RESULTS}

\subsection{Main results}

Table 8 presents the 2SLS estimates of the relationship between family influence and firm growth. Model 1 includes our main variable of interest, the Family dummy, while Models 2 adds WGI, our proxy for institutional environment, Model 3 adds the interaction between Family and $W G I_{c}$ and Models 4-9 report the results for all the individual dimensions of $W G I_{c}$.

\section{INSERT TABLE 8 HERE}

$\mathrm{H} 1$ predicts that family influence positively affects firm growth. In Table 8, the Family 
dummy is statistically significant, indicating that the average growth rate of family firms is in fact significantly higher than for non-family firms (Model 1: $\beta=0.013, \mathrm{p}<0.01$ ). In contrast to private family firms that do not differ in growth from their non-family counterparts (Chrisman et al., 2004), our publicly-traded family firms have, on average, a 1\% higher growth rate than their nonfamily counterparts. Our finding also contrasts with prior cross-sectional studies on family firm growth by Lee (2006) and Campopiano et al. (2019), very likely because our panel data allow us to obtain more accurate estimates of model parameters by observing growth rates over a longer period and covering different stages of the business cycle and of firm development (Evert et al., 2016). In addition, our identification strategy reduces endogeneity concerns via strong and valid IVs (Rose \& Stone, 2011), as confirmed by both Kleibergen-Paap and Hansen tests, and it also mitigates survivorship bias (Elton et al., 1996).

Model 2 of Table 8 assesses the effect of institutional development on firm growth. The coefficient of $W G I$ is positive and highly significant $(\beta=0.011 ; \mathrm{p}<0.001)$ suggesting that firms in countries with strong institutional development, on average, grow faster than firms from countries with weak institutional development, confirming the role of national institutions in boosting firm growth. In addition, after accounting for country-level institutional development, the Family coefficient increases in economic and statistical significance $(\beta=0.017 ; \mathrm{p}<0.001)$.

Model 3 indicates that the Family coefficient remains positive and statistically significant after incorporating the interaction between family influence and institutional development $(\beta=0.019 ; \mathrm{p}<0.001)$. The interaction between Family and WGI is also positive and significant $(\beta=0.015 ; \mathrm{p}<0.01)$. Holding all other variables constant, we calculated the economic impact of our regression estimates for family firms from countries with institutional development above the sample average: $(0.019+0.015) * 100=3.4 \%$ (statistically significant at the $1 \%$ level). Thus, the 
positive effect of family control on firm growth is greater in countries with superior institutional environments $(3.4 \%)$ than in countries with average institutional environments (1.9\%). This finding is confirmed in all other specifications of Table 8 (Models 4-9), with individual WGIs (Democratic Freedom, Government Effectiveness, Regulatory Quality, Rule of Law, Corruption Control and Political Stability) as dependent variables, and all firm-, industry- and country-level controls. Thus, our empirical evidence robustly supports H2. It is also important to mention that family firms grow more in average institutional environments $(\beta=0.019 ; \mathrm{p}<0.001)$ and in superior institutional environments $(\beta=0.034 ; \mathrm{p}<0.001)$, as compared to their nonfamily counterparts $(\beta=0.005 ; \mathrm{p}<0.186)$. Wald tests of the joint significance of industry and time dummies are statistically at the $1 \%$ level in all models, justifying their incorporation in our explanatory model.

To summarize, family firms have higher growth rates than non-family firms, thus supporting the long-term view of family firms. Moreover, this positive effect is greater in countries with strong national institutional environments, again in line with the long-term perspective of family business.

\subsection{Post-hoc analysis}

Thus far we have shown that, on average, family firms have higher growth rates than their nonfamily counterparts, particularly in countries with better institutional environments. We shall now proceed to explore whether these main findings vary across different types of family firms, industrial sectors and stages of the business cycle ${ }^{\text {iv }}$. Results are provided in Table 9.

INSERT TABLE 9 HERE

5.2.1 Variations across family firms 
Because studies show that different types of family involvement can affect firm dynamics and performance (Chrisman, Chua, Le Breton-Miller, Miller, \& Steier, 2017; Daspit, Chrisman, Sharma, Pearson, \& Mahto, 2018; Memili \& Dibrell, 2019), we assessed their impact on firm growth in different institutional environments. To this end, we re-estimated our main explanatory model for founders and for heirs and for their involvement in the firm management. We distinguish four clusters: 1) firms led by founder CEOs (Founder CEO); 2) non-executive founders (Founder non-executive); 3) heir CEOs (Descendant CEO); and 4) non-executive heirs (Descendant nonexecutive). Results are reported in Models 1 and 2 of Table 9.

Model 1 indicates that founder-led family firms exhibit faster growth than non-family firms and later-generation family firms $(\mathrm{p}<0.10)$, perhaps because founders are more talented, expert, and entrepreneurial. Interestingly, we do not find that later-generation firms have slower growth than non-family firms, as coefficients for Descendant CEO and Descendant non-executive are nonsignificant.

Model 2 shows a positive moderating effect of superior institutional development only for later-generation family firms led by professional (non-family) CEOs $(\beta=0.017 ; \mathrm{p}<0.097$ ). Thus, professional CEOs in later-generation family firms achieve superior growth only in countries with strong institutional environments.

In summary, first-generation family firms, on average, demonstrate higher growth rates than others regardless of whether the CEO is a family member or not, whereas later-generation family firms achieve faster growth but only with non-family CEOs and in countries with superior institutional development.

\subsubsection{Variations across industries}


We explored the role of Industry concentration in the relationship between family influence and firm growth, as captured by the Herfindahl-Hirschman Index (HHI) of segment market shares (Sraer \& Thesmar, 2007; Villalonga \& Amit, 2010). Family firms might have more difficulty growing in industries dominated by a few powerful rivals. Models 3-6 of Table 10 display results for industries with low concentration (those with HHI below the median) and high concentration (HHI above the median). The coefficients for Family and levels of statistical significance are similar in both models (Models 3 and 4). A parallel result is documented for family firm growth in countries with different institutional environments (Models 5 and 6). Thus, industry concentration does not appear to affect our results.

\subsubsection{Variation across business cycles}

We verified whether the financial crisis of 2007-2010 influenced the results of our study (Minichilli, Brogi, \& Calabrò, 2016) by dividing our sample into the two periods: the financial crisis (2007-2010) and normal economic times (2011-2016). The results are presented in Models (7)-(10) of Table 10. We find that the positive effect of family influence on growth is significant only during the normal economic period (Models 9: $\beta=0.023, \mathrm{p}<0.001$ ). The Family coefficient is negative during the financial crisis (Model 7: $\beta=-0.001$ ) but does not reach significance. Thus, family firm growth was similar to that of others during the financial crisis. However, family firms operating in countries with strong institutions grow faster than non-family firms, even during the financial crisis (Model 8: $\beta=0.048, \mathrm{p}<0.000$ ). Thus, the level of institutional development does matter for family firm growth in both good and bad economic times.

To summarize, we find that family firm type and business cycle factors significantly alter the positive effect of family influence on firm growth. 


\subsection{Robustness tests}

To validate our main findings, we performed several robustness tests using alternative variable definitions and alternative model specifications. We re-ran our model using alternative definitions of our dependent variable (Panel A of Table 10) as follows: 1) Absolute growth rate in total assets for company $i$ from country $c$ between time $t$ and $t-1$ (Models 1-2); 2) Relative growth rate in total assets for company $i$ from country $c$ between time $t$ and $t-1$ (Models 3-4); 3) Relative growth rate in sales for company $i$ from country $c$ between time $t$ and $t-1$ (Models 5-6); 4) Return on Assets (ROA) defined as the ratio between earnings before interest, taxes, depreciation and amortization divided by total assets for company $i$ from country $c$ (winsorized at the $1 \%$ level) (Models 7-8) ${ }^{\mathrm{v}}$. In most of the specifications, we obtain similar results for both magnitude and direction of the main effects reported in Table 10. However, in a few cases they lacked statistical significance, perhaps because different growth measures assess different qualities (Shepherd \& Wiklund, 2009). In addition, we re-estimated our model using an alternative family firm definition (a dummy variable that equals one if the founder or descendant or family member is director or large shareholder owning more than 5\% of the firm's equity, zero otherwise) and found strong support for both H1 and H2 (Models 9 and 10 of Table 10).

\section{INSERT TABLE 10 HERE}

We also re-estimated our explanatory model by including additional control variables (Panel B of Table 10): 1) Industry concentration estimated as the HHI (sum of squared market shares using segment sales at the industry level) (Models 1-2); 2) Innovation output estimated as the brands and patents-to-net-sales ratio (Models 3-4); 3) Public spending estimated as cash payments for operating activities of the government in providing goods and services (this includes compensation 
of employees, interest and subsidies, grants, social benefits, and expenses such as rent and dividends) (Models 5-6); 4) Internationalization calculated as the ratio between foreign sales and net sales (Models 7-8); 5) Population size calculated as logarithm of country's population (Models 9-10); 6) All the afore-mentioned additional controls were included simultaneously (Models 1112).

\section{DISCUSSION AND IMPLICATIONS}

The agency view and much of the SEW perspective suggest that the growth prospects of family firms are limited (Miller \& Le Breton-Miller, 2014). Rationales include extraction of private benefits, risk aversion, lack of resources, and entrenchment of incompetent family members. By contrast, the long-term orientation view suggests that many family firms have long time horizons and invest generously in their companies; that in turn fuels their superior growth. In this study, we compare the ability of the agency versus long-term orientation views to explain the growth rate of family firms and the concomitant impact of the institutional context.

We find that family influence does in general increase firm growth. However, this is far truer in countries with a sounder institutional environment; specifically, countries that are more democratic, have more effective governing policies, are less corrupt, and where the rule of law prevails. These findings hold after controlling for endogeneity and sample selection, and adopting alternative model specifications and control variables. We also find that the positive effect of family influence on firm growth varies significantly across different types of family firms and different business cycles.

Our results appear to confirm the long-term orientation of many family firms. Arregle et al. (2007); Block and Henkel (2010); Chrisman, Chua and Steier, 2011; Miller et al. (2008); Miller 
\& Le Breton-Miller $(2005 ; 2014)$ and others have argued that family firms are concerned with the long-term future of the business to support the careers, financial, and social circumstances of current and later generations. As a result, many families tend to have longer time horizons - to invest more in their companies than diffusely owned firms with agent executives who are pressured to deliver quarterly earnings and have less at stake in long-term outcomes. Such a long-term orientation can promote growth.

However, where a long-term orientation is discouraged or stymied by an institutional climate that makes the future highly uncertain, and therefore investments in the long term less likely to pay off, then family firms will be less likely to invest, and their long-term growth can be slower than otherwise. Indeed, where the institutional environment is undemocratic, underdeveloped, corrupt, ineffective, or risky, families may, in line with agency expectations (Morck et al., 2005), extract private benefits from their public companies to build a private family nest egg, thereby hobbling firm growth. Under those circumstances, financial security and social position are more likely to reside in the family rather than the business (Björnberg, Dias, \& Elstrodt, 2016). That is exactly what our analysis suggests ${ }^{\mathrm{vi}}$.

\subsection{Theoretical implications}

Our study makes several theoretical contributions. First, we condition the principal-principal agency perspective by showing that family influence is on average beneficial to firm growth. We also show how that effect varies across different types of family firms, economies, and business cycles in publicly traded firms around the globe, where family firms are often of paramount economic importance (Barontini \& Caprio, 2006; De Massis, Frattini, Majocchi, \& Piscitello, 2017; European Commission, 2009; European Family Business Barometer, 2017; Faccio \& Lang, 
2002).

Second, we demonstrate which national institutions boost family firm growth, showing that firms grow faster in countries with more democracy, government effectiveness, regulatory quality, rule of law, corruption control and political stability. We also document how the positive moderating effect of the institutional environment varies across different types of family firms and different business cycles. Thus, we highlight the importance of studying the interplay between micro- and macro-level factors.

Finally, family business research has been plagued by endogeneity problems (Evert et al., 2016), particularly the firm growth literature (Casillas, Moreno, \& Barbero, 2010; Lee, 2006; McConaughy \& Phillips, 1999; Sraer \& Thesmar, 2007). We have strived to mitigate that issue along with sample selection bias using panel data and instrumental variable (IV) estimators. We also employed a battery of robustness tests to rule out alternative explanations. Thus, we provide solid insights into family firms growth.

\subsection{Practical implications}

Our study also has practical implications. Debates abound in the regulatory, business, and academic communities over policies to promote firm growth, worldwide (David, Albert, Mary, Erik, \& Niels, 2015; Rubini, Desmet, Piguillem, \& Crespo, 2012). We show that the institutional environment has an important effect on firm growth, and that this differs based on firm ownership and governance conditions. Policy-makers and potential investors must heed the institutional environment when evaluating growth potential.

Managers and consultants in promoting family firm growth may do well to consider the business cycle. Growth promotion initiatives may succeed better during normal economic times; 
conservative growth strategies may be better during financial crises. In other words, growth strategies could be adapted to the business cycle.

\subsection{Limitations and future research}

We also acknowledge the limitations of our work, which can present fruitful avenues for future research. As many other studies examining long-term orientation in family business (Le BretonMiller \& Miller, 2006; Miller \& Le Breton-Miller, 2005), this study also does not directly measure long-term orientation associated with a firm's strategic decision to grow. Nevertheless, we perform a wide range of sensitivity tests to rule out alternative explanations of our main results highlighting that the growth rate of a firm is indeed a function of family firms' long-term orientation. Therefore, we encourage future studies analyzing the growth of family and non-family firms to examine the validity of our findings, measuring different aspects of long-term orientation (Le Breton-Miller \& Miller, 2006).

Data limitations prevented us from studying private family firms. Recent research suggests that such firms, insulated from financial markets, have more balanced temporal horizons and different investment strategies than listed family firms (Carney, Van Essen, Gedajlovic, \& Heugens, 2015). Others show that private family firms can be excessively altruistic towards their descendants, thereby creating organizational inefficiencies (Schulze, Lubatkin, \& Dino, 2002; Schulze, Lubatkin, Dino, \& Buchholtz, 2001). Thus, analyzing private family firms' growth dynamics will be an important initiative. We also hope that others will study organic versus acquisitive growth (McKelvie \& Wiklund, 2010), and growth in small and medium-size firms, and at different stages of their development.

Finally, family firm growth may be affected by the personal characteristics of family and non-family managers (i.e. education, age, professional background and etc.), as well as 
governance qualities such as executive compensation, board of directors functioning and structure, and corporate takeovers (Daspit et al., 2018). We encourage future studies to investigate such influences.

\section{CONCLUSION}

Our study has examined the neglected topic of family business growth based on a sample of 5,265 publicly traded firms from 43 countries in 33 industrial sectors from 2007 to 2016. Consistent with the long-term view of family business (Miller \& Le Breton-Miller, 2005, 2014; Lumpkin \& Brigham, 2011), we find that family firms on average have higher growth rate than non-family firms and this positive effect is significantly stronger in countries with superior institutional environments. These results remain unchanged after correcting for endogeneity, accounting for potential sample selection problem, using alternative variable definitions, and including additional control variables. We also find that the positive effect of family influence on firm growth is stronger for family firms during normal economic times. All in all, our findings highlight that family influence is a significant determinant of firm growth, but the magnitude of that effect depends very much on the type of family business, the institutional context and the business cycle.

\section{REFERENCES}

Acemoğlu, D., Naidu, S., Restepo, P., \& Robinson, J. A. (in press). Democracy does cause growth. Journal of Political Economy.

Afshartous, D., \& Preston, R. A. (2011). Key Results of Interaction Models with Centering. Journal of Statistics Education, 19(3), 1-24. doi:10.1080/10691898.2011.11889620

Aguilera, R. V., \& Jackson, G. (2003). The Cross-National Diversity of Corporate Governance: Dimensions and Determinants. Academy of Management Review, 28(3), 447-465. doi: $10.2307 / 30040732$

Ahuja, G., Capron, L., Lenox, M., \& Yao, D. A. (2018). Strategy and the Institutional Envelope. Strategy Science, 3(2), ii-x. doi:10.1287/stsc.2018.0062

Ali, A., Chen, T.-Y., \& Radhakrishnan, S. (2007). Corporate disclosures by family firms. Journal of Accounting and Economics, 44(1), 238-286. doi:https://doi.org/10.1016/j.jacceco.2007.01.006 
Allen, F., Qian, J., \& Qian, M. (2005). Law, finance, and economic growth in China. Journal of Financial Economics, 77(1), 57-116. doi:https://doi.org/10.1016/j.jfineco.2004.06.010

Amit, R., Ding, Y., Villalonga, B., \& Zhang, H. (2015). The role of institutional development in the prevalence and performance of entrepreneur and family-controlled firms. Journal of Corporate Finance, 31, 284-305. doi:https://doi.org/10.1016/j.jcorpfin.2015.01.001

Anderson, R. C., \& Reeb, D. M. (2003a). Founding-Family Ownership and Firm Performance: Evidence from the S\&P 500 Journal of Finance, 58(3), 1301-1328.

Anderson, R. C., \& Reeb, D. M. (2003b). Founding-Family Ownership, Corporate Diversification, and Firm Leverage. The Journal of Law \& Economics, 46(2), 653-684. doi:10.1086/377115

Apergis, N. (2004). Inflation, output growth, volatility and causality: evidence from panel data and the G7 countries. Economics Letters, 83(2), 185-191. doi:https://doi.org/10.1016/j.econlet.2003.11.006

Arregle, J. L., Hitt, M. A., Sirmon, D. G., \& Very, P. (2007). The Development of Organizational Social Capital: Attributes of Family Firms. Journal of Management Studies, 44(1), 73-95. doi:10.1111/j.1467-6486.2007.00665.x

Audretsch, D. B., Coad, A., \& Segarra, A. (2014). Firm growth and innovation. Small Business Economics, 43(4), 743-749.

Bakker, A. B., \& Schaufeli, W. B. (2008). Positive organizational behavior: engaged employees in flourishing organizations. Journal of Organizational Behavior, 29(2), 147-154. doi:10.1002/job.515

Banalieva, E. R., Eddleston, K. A., \& Zellweger, T. M. (2014). When do family firms have an advantage in transitioning economies? Toward a dynamic institution-based view. Strategic Management Journal, 36(9), 1358-1377. doi:10.1002/smj.2288

Barontini, R., \& Bozzi, S. (2018). Family firm heterogeneity and CEO compensation in Continental Europe. Journal of Economics and Business. doi:10.1016/j.jeconbus.2018.02.001

Barontini, R., \& Caprio, L. (2006). The Effect of Family Control on Firm Value and Performance: Evidence from Continental Europe. European Financial Management, 12(5), 689-723. doi:DOI 10.1111/j.1468-036X.2006.00273.X

Baù, M., Chirico, F., Pittino, D., Backman, M., \& Klaesson, J. (2018). Roots to Grow: Family Firms and Local Embeddedness in Rural and Urban Contexts. Entrepreneurship Theory and Practice. doi: $10.1177 / 1042258718796089$

Baum, C. F., Schaffer, M. E., \& Stillman, S. (2003). Instrumental Variables and GMM: Estimation and Testing. The Stata Journal, 3(1), 1-31. doi:10.1177/1536867X0300300101

Beck, T., Demirguc-Kunt, A., Laeven, L. U. C., \& Levine, R. (2008). Finance, Firm Size, and Growth. Journal of Money, Credit and Banking, 40(7), 1379-1405. doi:10.1111/j.1538-4616.2008.00164.x

Bergfeld, M.-M. H., \& Weber, F.-M. (2011). Dynasties of innovation: highly performing German family firms and the owners' role for innovation. International Journal of Entrepreneurship and Innovation Management, 13(1).

Berrone, P., Cruz, C., \& Gomez-Mejia, L. R. (2012). Socioemotional Wealth in Family Firms: Theoretical Dimensions, Assessment Approaches, and Agenda for Future Research. Family Business Review, 25(3), 258-279. doi:10.1177/0894486511435355

Berrone, P., Cruz, C., Gomez-Mejia, L. R., \& Larraza-Kintana, M. (2010). Socioemotional Wealth and Corporate Responses to Institutional Pressures: Do Family-Controlled Firms Pollute Less? Administrative Science Quarterly, 55(1), 82-113. doi:10.2189/asqu.2010.55.1.82

Bertrand, M., \& Schoar, A. (2006). The role of family in family firms. Journal of Economic Perspectives, 20(2), 73-96.

Björnberg, Å., Dias, A. K., \& Elstrodt, H.-P. (2016). Fine-tuning family businesses for a new era. Retrieved from

Blair, M. M., \& Stout, L. A. (2006). Specific Investment: Explaining Anomalies in Corporate Law. Journal of Corporation Law, 31(3), 719-744.

Block, J. H. (2012). R\&D investments in family and founder firms: An agency perspective. Journal of Business Venturing, 27(2), 248-265. doi:https://doi.org/10.1016/j.jbusvent.2010.09.003 
Block, J. H., \& Henkel, J. (2010). Long-term Orientation of Family Firms: An Investigation of R\&D Investments, Downsizing Practices, and Executive Pay Gabler Verlag.

Bloom, N., \& Van Reenen, J. (2007). Measuring and Explaining Management Practices across Firms and Countries. The Quarterly Journal of Economics, 122(4), 1351-1408.

Bozzi, S., Barontini, R., \& Miroshnychenko, I. (2017). Investor protection and CEO compensation in family firms. Corporate Ownership and Control, 14(2), 17-29.

Brigham, K. H., Lumpkin, G. T., Payne, G. T., \& Zachary, M. A. (2013). Researching Long-Term Orientation: A Validation Study and Recommendations for Future Research. Family Business Review, 27(1), 72-88. doi:10.1177/0894486513508980

Brown, J. R., \& Petersen, B. C. (2009). Why has the investment-cash flow sensitivity declined so sharply? Rising R\&D and equity market developments. Journal of Banking \& Finance, 33(5), 971984. doi:10.1016/j.jbankfin.2008.10.009

Campopiano, G., Brumana, M., Minola, T., \& Cassia, L. (2019). Does Growth Represent Chimera or Bellerophon for a Family Business? The Role of Entrepreneurial Orientation and Family Influence Nuances. European Management Review, n/a(n/a). doi:10.1111/emre.12351

Carney, M., Van Essen, M., Gedajlovic, E. R., \& Heugens, P. P. M. A. R. (2015). What Do We Know About Private Family Firms? A Meta-Analytical Review. Entrepreneurship Theory and Practice, 39(3), 513-544. doi:10.1111/etap.12054

Casillas, Moreno, A. M., \& Barbero, J. L. (2010). A Configurational Approach of the Relationship Between Entrepreneurial Orientation and Growth of Family Firms. Family Business Review, 23(1), 2744. doi:10.1177/0894486509345159

Cennamo, C., Berrone, P., Cruz, C., \& Gomez-Mejia, L. R. (2012). Socioemotional Wealth and Proactive Stakeholder Engagement: Why Family-Controlled Firms Care More About Their Stakeholders. Entrepreneurship Theory and Practice, 36(6), 1153-1173. doi:10.1111/j.1540-6520.2012.00543.x

Chen, Firth, M., Gao, D. N., \& Rui, O. M. (2006). Ownership structure, corporate governance, and fraud: Evidence from China. Journal of Corporate Finance, 12(3), 424-448. doi:https://doi.org/10.1016/j.jcorpfin.2005.09.002

Chen, Hou, W., Li, W., Wilson, C., \& Wu, Z. (2014). Family Control, Regulatory Environment, and the Growth of Entrepreneurial Firms: International Evidence. Corporate Governance: An International Review, 22(2), 132-144. doi:10.1111/corg. 12060

Chrisman, J. J., Chua, J. H., Le Breton-Miller, I., Miller, D., \& Steier, L. P. (2017). Governance Mechanisms and Family Firms. Entrepreneurship Theory and Practice, 42(2), 171-186. doi:10.1177/1042258717748650

Chrisman, J. J., Chua, J. H., \& Litz, R. A. (2004). Comparing the Agency Costs of Family and NonFamily Firms: Conceptual Issues and Exploratory Evidence. Entrepreneurship Theory and Practice, 28(4), 335-354. doi:10.1111/j.1540-6520.2004.00049.x

Chrisman, J. J., Chua, J. H., \& Steier, L. (2011). Resilience of family firms: An introduction. Entrepreneurship Theory and Practice, 35(6), 1107-1119.

Chrisman, J. J., \& Patel, P. C. (2012). Variations in R\&D Investments of Family and Nonfamily Firms Behavioral Agency and Myopic Loss Aversion Perspectives. Academy of Management Journal, 55(4), 976-997. doi:10.5465/ami.2011.0211

Chua, Chrisman, J. J., \& Sharma, P. (1999). Defining the Family Business by Behavior Entrepreneurship Theory and Practice, 23(4), 19-39.

Ciravegna, L., Kano, L., Rattalino, F., \& Verbeke, A. (2019). Corporate Diplomacy and Family Firm Longevity. Entrepreneurship Theory and Practice, 1042258719838477. doi:10.1177/1042258719838477

Craig, J. B., Dibrell, C., \& Davis, P. S. (2008). Leveraging Family-Based Brand Identity to Enhance Firm Competitiveness and Performance in Family Businesses. Journal of Small Business Management, 46(3), 351-371. doi:10.1111/j.1540-627X.2008.00248.x

Crouzet, F. (1999). Business dynasties in Britain and France. Elites, Minorities and Economic Growth. New-York: Elsevier, North-Holland. 
Daspit, J. J., Chrisman, J. J., Sharma, P., Pearson, A. W., \& Mahto, R. V. (2018). Governance as a Source of Family Firm Heterogeneity. Journal of Business Research, 84, 293-300.

doi:10.1016/j.jbusres.2017.12.041

David, B. A., Albert, N. L., Mary, W., Erik, S., \& Niels, B. (2015). Local Policies for High-Growth Firms. In The Oxford Handbook of Local Competitiveness: Oxford University Press.

Davidson, P., Delmar, F., \& Wiklund, J. (2006). Entrepreneurship and the Growth of Firms: Edward Elgar.

De Massis, A., Audretsch, D., Uhlaner, L., Kammerlander, N. (2018). Innovation with limited resources: Management lessons from the German Mittelstand. Journal of Product Innovation Management, 35(1), 125-146.

De Massis, A., Frattini, F., Majocchi, A., \& Piscitello, L. (2017). Family firms in the global economy: Toward a deeper understanding of internationalization determinants, processes, and outcomes. Global Strategy Journal, 8(1), 3-21. doi:10.1002/gsj.1199

De Massis, A., Frattini, F., Pizzurno, E., \& Cassia, L. (2015). Product Innovation in Family versus Nonfamily Firms An Exploratory Analysis. Journal of Small Business Management, 53(1), 1-36.

Del Monte, A., \& Papagni, E. (2003). R\&D and the growth of firms: empirical analysis of a panel of Italian firms. Research Policy, 32(6), 1003-1014. doi:https://doi.org/10.1016/S0048-7333(02)00107-5

Demsetz, H., \& Villalonga, B. (2001). Ownership structure and corporate performance. Journal of Corporate Finance, 7(3), 209-233. doi:https://doi.org/10.1016/S0929-1199(01)00020-7

Ding, S., Qu, B., \& Wu, Z. (2016). Family Control, Socioemotional Wealth, and Governance Environment: The Case of Bribes. Journal of Business Ethics, 136(3), 639-654.

Dittmar, A., Mahrt-Smith, J., \& Servaes, H. (2003). International Corporate Governance and Corporate Cash Holdings. The Journal of Financial and Quantitative Analysis, 38(1), 111-133. doi:10.2307/4126766

Dorrenbacher, C., Tomenendal, M., \& Stanske, S. (2017). Organizational Identity and Firm Growth. UK: Palgrave Macmillan

Duran, P., Kammerlander, N., Van Essen, M., \& Zellweger, T. (2016). Doing More with Less Innovation Input and Output in Family Firms. Academy of Management Journal, 59(4), 1224-1264.

Dyck, A., \& Zingales, L. (2004). Private Benefits of Control: An International Comparison. The Journal of Finance, 59(2), 537-600.

Dyer, W. G., \& Whetten David, A. (2006). Family Firms and Social Responsibility: Preliminary Evidence from the S\&P 500. Entrepreneurship Theory and Practice, 30(6), 785-802. doi:10.1111/j.15406520.2006.00151.X

Eddleston, K. A., \& Kellermanns, F. W. (2007). Destructive and productive family relationships: A stewardship theory perspective. Journal of Business Venturing, 22(4), 545-565. doi:https://doi.org/10.1016/j.jbusvent.2006.06.004

Elton, E. J., Gruber, M. J., \& Blake, C. R. (1996). Survivorship Bias and Mutual Fund Performance. The Review of Financial Studies, 9(4), 1097-1120.

European Commission. (2009). Overview of family business relevant issues: Research, networks, policy measures and existing studies. Retrieved from

European Family Business Barometer. (2017). Confidence in Unity. Retrieved from https://home.kpmg.com/xx/en/home/insights/2017/11/european-family-business-barometerconfidence-in-unity-sixth-edition.html

Evert, R. E., Martin, J. A., McLeod, M. S., \& Payne, G. T. (2016). Empirics in Family Business Research. Family Business Review, 29(1), 17-43. doi:10.1177/0894486515593869

Faccio, M., \& Lang, L. H. P. (2002). The ultimate ownership of Western European corporations. Journal of Financial Economics, 65(3), 365-395.

Fama, E. F., \& Jensen, M. C. (1983). Separation of Ownership and Control. Journal of Law and Economics, 26(2), 301-325.

Filbeck, G., \& Lee, S. (2000). Financial Management Techniques in Family Businesses. Family Business Review, 13(3), 201-216. doi:10.1111/j.1741-6248.2000.00201.x 
Fontana, G., \& Srivastava, A. (2009). A Human Capital Approach to Inequalities: The Case of the East Asian Miracle and India. Journal of Economic Issues, 43(2), 523-530. doi:10.2753/JEI00213624430226

Gale, W. G., \& Scholz, J. K. (1994). Intergenerational Transfers and the Accumulation of Wealth. Journal of Economic Perspectives, 8(4), 145-160. doi:10.1257/jep.8.4.145

García-Manjón, J. V., \& Romero-Merino, M. E. (2012). Research, development, and firm growth. Empirical evidence from European top R\&D spending firms. Research Policy, 41(6), 1084-1092. doi:https://doi.org/10.1016/j.respol.2012.03.017

Geroski, P., \& Machin, S. (1992). Do Innovating Firms Outperform Non-Innovators?*. Business Strategy Review, 3(2), 79-90. doi:10.1111/j.1467-8616.1992.tb00030.x

Giannetti, M. (2003). Do Better Institutions Mitigate Agency Problems? Evidence from Corporate Finance Choices. The Journal of Financial and Quantitative Analysis, 38(1), 185-212. doi:10.2307/4126769

Goedhuys, M., \& Sleuwaegen, L. (2016). High-growth versus declining firms: the differential impact of human capital and R\&D. Applied Economics Letters, 23(5), 369-372. doi:10.1080/13504851.2015.1076139

Gómez-Mejía, Campbell, J. T., Martin, G., Hoskisson, R. E., Makri, M., \& Sirmon, D. G. (2013). Socioemotional Wealth as a Mixed Gamble: Revisiting Family Firm R\&D Investments With the Behavioral Agency Model. Entrepreneurship Theory and Practice, 38, 1351-1374.

Gómez-Mejía, Makri, M., \& Kintana, M. L. (2010). Diversification Decisions in Family-Controlled Firms. Journal of Management Studies, 47(2), 223-252. doi:10.1111/j.1467-6486.2009.00889.x

Gómez-Mejía, L. R., Campbell, J. T., Martin, G., Hoskisson, R. E., Makri, M., \& Sirmon, D. G. (2014). Socioemotional wealth as mixed gamble. Entrepreneurship Theory and Practice, 38, 1351-1374.

Gómez-Mejía, L. R., Haynes, K. T., Nunez-Nickel, M., Jacobson, K. J. L., \& Moyano-Fuentes, J. (2007). Socioemotional Wealth and Business Risks in Family-controlled Firms: Evidence from Spanish Olive Oil Mills Administrative Science Quarterly, 52, 106-137.

Grover Goswami, A., Medvedev, D., \& Olafsen, E. (2019). High-Growth Firms : Facts, Fiction, and Policy Options for Emerging Economies. Washington, DC: World Bank.

Gudmundson, D., Hartman, E. A., \& Tower, C. B. (2004). Strategic Orientation: Differences between Family and Nonfamily Firms. Family Business Review, 12(1), 27-39. doi:10.1111/j.17416248.1999.00027.x

Gulati, U. C. (1992). The Foundations of Rapid Economic Growth: The Case of the Four Tigers. The American Journal of Economics and Sociology, 51(2), 161-172.

Habbershon, T. G., \& Williams, M. L. (1999). A Resource-Based Framework for Assessing the Strategic Advantages of Family Firms. Family Business Review, 12(1), 1-25. doi:10.1111/j.17416248.1999.00001.X

Hardwick, P., \& Adams, M. (2002). Firm Size and Growth in the United Kingdom Life Insurance Industry. The Journal of Risk and Insurance, 69(4), 577-593.

Harrington, B. (2016). Capital without Borders: Wealth Managers and the One Percent. Cambridge: Harvard University Press.

Heckman, J. J. (1979). Sample Selection Bias as a Specification Error. Econometrica, 47(1), 153-161. doi:10.2307/1912352

Huynh, K. P., \& Petrunia, R. J. (2010). Age effects, leverage and firm growth. Journal of Economic Dynamics and Control, 34(5), 1003-1013. doi:https://doi.org/10.1016/j.jedc.2010.01.007

Kang, J.-K., \& Kim, J. (2019). Do Family Firms Invest More than Nonfamily Firms in EmployeeFriendly Policies? Management Science. doi:10.1287/mnsc.2018.3231

Kao, J. (1993). The worldwide web of Chinese businesses. Harvard Business Review, 71, 24-36.

Kappes, I., \& Schmid, T. (2013). The Effect of Family Governance on Corporate Time Horizons. Corporate Governance: An International Review, 21(6), 547-566. doi:10.1111/corg.12040 
Kaufmann, D., Kraay, A., \& Mastruzzi, M. (2011). The Worldwide Governance Indicators: Methodology and Analytical Issues. Hague Journal on the Rule of Law, 3(2), 220-246. doi:10.1017/S1876404511200046

Khanna, T., \& Palepu, K. (2000). Is Group Affiliation Profitable in Emerging Markets? An Analysis of Diversified Indian Business Groups. The Journal of Finance, 55(2), 867-891. doi:10.1111/00221082.00229

Koh, P.-S., \& Reeb, D. M. (2015). Missing R\&D. Journal of Accounting and Economics, 60(1), 73-94. doi:10.1016/j.jacceco.2015.03.004

Kotlar, J., \& De Massis, A. (2013). Goal Setting in Family Firms: Goal Diversity, Social Interactions, and Collective Commitment to Family-Centered Goals. Entrepreneurship Theory and Practice, 37(6), 1263-1288. doi:10.1111/etap.12065

Kotlar, J., Fang, H., De Massis, A., \& Frattini, F. (2014). Profitability Goals, Control Goals, and the R\&D Investment Decisions of Family and Nonfamily Firms. Journal of Product Innovation Management, 31(6), 1128-1145. doi:10.1111/jpim.12165

Kotlar, J., Signori, A., De Massis, A., \& Vismara, S. (2018). Financial wealth, sociemotional wealth and IPO underpricing in family firms: A two-stage gamble model. Academy of Management Journal.

Krafft, J., Qu, Y., Quatraro, F., \& Ravix, J. L. (2013). Corporate governance, value and performance of firms: new empirical results on convergence from a large international database. Industrial and Corporate Change, 23(2), 361-397. doi:10.1093/icc/dtt007

Krueger, A. O. (1974). The Political Economy of the Rent-Seeking Society. The American Economic Review, 64(3), 291-303.

La Porta, R., Lopez-de-Silanes, F., \& Shleifer, A. (2013). Chapter 6 - Law and Finance After a Decade of Research. In G. M. Constantinides, M. Harris, \& R. M. Stulz (Eds.), Handbook of the Economics of Finance (Vol. 2, pp. 425-491): Elsevier.

La Porta, R., Lopez-de-Silanes, F., Shleifer, A., \& Vishny, R. (2000). Investor protection and corporate governance. Journal of Financial Economics, 58(1), 3-27. doi:https://doi.org/10.1016/S0304405X(00)00065-9

La Porta, R., Lopez-De-Silanes, F., \& Shleifer, A. (1999). Corporate Ownership Around the World. The Journal of Finance, 54(2), 471-517. doi:10.1111/0022-1082.00115

Lamb, N. H., \& Butler, F. C. (2016). The Influence of Family Firms and Institutional Owners on Corporate Social Responsibility Performance. Business \& Society, 57(7), 1374-1406. doi:10.1177/0007650316648443

Le Breton-Miller, I., \& Miller, D. (2006). Why Do Some Family Businesses Out-Compete? Governance, Long-Term Orientations, and Sustainable Capability. Entrepreneurship Theory and Practice, 30(6), 731-746. doi:10.1111/j.1540-6520.2006.00147.x

Le Breton-Miller, I., \& Miller, D. (2018). Looking Back at and Forward From: "Family Governance and Firm Performance: Agency, Stewardship, and Capabilities”. Family Business Review, 31(2), 229-237. doi:10.1177/0894486518773850

Le Breton-Miller, I., Miller, D., \& Lester, R. H. (2010). Stewardship or Agency? A Social Embeddedness Reconciliation of Conduct and Performance in Public Family Businesses. Organization Science, 22(3), 704-721. doi:10.1287/orsc.1100.0541

Lee, J. (2006). Family firm performance: Further evidence. Family Business Review, 19(2), 103-114.

Leuz, C., \& Oberholzer-Gee, F. (2006). Political relationships, global financing, and corporate transparency: Evidence from Indonesia. Journal of Financial Economics, 81(2), 411-439. doi:https://doi.org/10.1016/j.jfineco.2005.06.006

Levine, R., Loayza, N., \& Beck, T. (2000). Financial intermediation and growth: Causality and causes. Journal of Monetary Economics, 46(1), 31-77. doi:https://doi.org/10.1016/S0304-3932(00)00017-9

Lumpkin, G. T., \& Brigham Keith, H. (2011). Long-Term Orientation and Intertemporal Choice in Family Firms. Entrepreneurship Theory and Practice, 35(6), 1149-1169. doi:10.1111/j.15406520.2011.00495.X 
McConaughy, D. L., \& Phillips, G. M. (1999). Founders versus Descendants: The Profitability, Efficiency, Growth Characteristics and Financing in Large, Public, Founding-Family-Controlled Firms. Family Business Review, 12(2), 123-131.

McKelvie, A., \& Wiklund, J. (2010). Advancing Firm Growth Research: A Focus on Growth Mode Instead of Growth Rate. Entrepreneurship Theory and Practice, 34(2), 261-288. doi:10.1111/j.15406520.2010.00375.X

Mehrotra, V., Morck, R., Shim, J., \& Wiwattanakantang, Y. (2013). Adoptive expectations: Rising sons in Japanese family firms. Journal of Financial Economics, 108(3), 840-854. doi:https://doi.org/10.1016/j.jfineco.2013.01.011

Memili, E., \& Dibrell, C. (2019). The Palgrave Handbook of Heterogeneity among Family Firms: Palgrave Macmillan, Cham, Switzerland.

Miller, D., \& Le Breton-Miller, I. (2005). Managing for the Long Run. Boston: Harvard Business School Press.

Miller, D., Le Breton-Miller, I., \& Lester, R. H. (2007). Divided loyalties: Governance, conduct and performance in family and entrepreneur businesses. Academy of Management Proceedings, 2007(1), 1-6. doi:10.5465/ambpp.2007.26508367

Miller, D., Le Breton-Miller, I., Lester, R. H., \& Cannella, A. A. (2007). Are family firms really superior performers? Journal of Corporate Finance, 13(5), 829-858. doi:10.1016/j.jcorpfin.2007.03.004

Miller, D., Le Breton-Miller, I., \& Scholnick, B. (2008). Stewardship vs. Stagnation: An Empirical Comparison of Small Family and Non-Family Businesses. Journal of Management Studies, 45(1), 5178. doi:10.1111/j.1467-6486.2007.00718.x

Miller, D., Xu, X., \& Mehrotra, V. (2014). When is human capital a valuable resource? The performance effects of Ivy league selection among celebrated CEOs. Strategic Management Journal, 36(6), 930944. doi:10.1002/smj.2251

Minichilli, A., Brogi, M., \& Calabrò, A. (2016). Weathering the Storm: Family Ownership, Governance, and Performance Through the Financial and Economic Crisis. Corporate Governance: An International Review, 24(6), 552-568. doi:10.1111/corg.12125

Mishra, C. S., \& McConaughy, D. L. (1999). Founding Family Control and Capital Structure: The Risk of Loss of Control and the Aversion to Debt. Entrepreneurship Theory and Practice, 23(4), 53-64. doi:10.1177/104225879902300404

Molly, V., Uhlaner, L., De Massis, A., \& Laveren, E. (in press). Family-centered goals, family board representation, and debt financing. Small Business Economics.

Morck, R., Wolfenzon, D., \& Yeung, B. (2005). Corporate Governance, Economic Entrenchment, and Growth. Journal of Economic Literature, 43(3), 655-720. doi:10.1257/002205105774431252

Morck, R., \& Yeung, B. (2003). Agency Problems in Large Family Business Groups. Entrepreneurship Theory and Practice, 27(4), 367-382. doi:10.1111/1540-8520.t01-1-00015

Morck, R., \& Yeung, B. (2004). Family control and the Rent-seeking society. Entrepreneurship Theory and Practice, 28, 391-409.

Muñoz-Bullón, F., \& Sanchez-Bueno, M. J. (2011). The Impact of Family Involvement on the R\&D Intensity of Publicly Traded Firms. Family Business Review, 24(1), 62-70. doi:10.1177/0894486510396870

Murphy, K. M., Shleifer, A., \& Vishny, R. W. (1993). Why Is Rent-Seeking So Costly to Growth? The American Economic Review, 83(2), 409-414.

North, D. C. (1990). Institutions, institutional change and economic performance. Cambridge, England: Cambridge University Press.

O'Boyle, E. H., Rutherford, M. W., \& Pollack, J. M. (2010). Examining the Relation Between Ethical Focus and Financial Performance in Family Firms: An Exploratory Study. Family Business Review, 23(4), 310-326. doi:10.1177/0894486510375412

O'Brien, R. M. (2007). A Caution Regarding Rules of Thumb for Variance Inflation Factors. Quality \& Quantity, 41(5), 673-690. 
O'Connor, M., \& Rafferty, M. (2012). Corporate Governance and Innovation. Journal of Financial and Quantitative Analysis, 47(2), 397-413. doi:10.1017/S002210901200004X

Oliveira, B., \& Fortunato, A. (2006). Testing Gibrat's Law: Empirical Evidence from a Panel of Portuguese Manufacturing Firms. International Journal of the Economics of Business, 13(1), 65-81. doi:10.1080/13571510500519996

Orth, U. R., \& Green, M. T. (2009). Consumer loyalty to family versus non-family business: The roles of store image, trust and satisfaction. Journal of Retailing and Consumer Services, 16(4), 248-259. doi:https://doi.org/10.1016/j.jretconser.2008.12.002

Oswald, A. J., Proto, E., \& Sgroi, D. (2015). Happiness and Productivity. Journal of Labor Economics, 33(4), 789-822. doi:10.1086/681096

Papaioannou, E., \& Siourounis, G. (2008). Democratisation and Growth. The Economic Journal, 118(532), 1520-1551. doi:10.1111/j.1468-0297.2008.02189.x

Patel, P. C., \& Chrisman, J. J. (2014). Risk abatement as a strategy for R\&D investments in family firms. Strategic Management Journal, 35(4), 617-627. doi:10.1002/smj.2119

Peng, M. W., \& Jiang, Y. (2010). Institutions Behind Family Ownership and Control in Large Firms. Journal of Management Studies, 47(2), 253-273. doi:10.1111/j.1467-6486.2009.00890.x

Peng, M. W., Sun, S. L., Pinkham, B., \& Chen, H. (2009). The institution-based view as a third leg for a strategy tripod. Academy of Management Perspectives, 23(3), 63-81.

Pérez-González, F. (2006). Inherited control and firm performance. American Economic Review, 96(5), 1559-1588.

Petersen, M. A. (2009). Estimating Standard Errors in Finance Panel Data Sets: Comparing Approaches. Review of Financial Studies, 22(1), 435-480. doi:10.1093/rfs/hhn053

Rahaman, M. M. (2011). Access to financing and firm growth. Journal of Banking \& Finance, 35(3), 709-723. doi:https://doi.org/10.1016/j.jbankfin.2010.09.005

Reid, R., Dunn, B., Cromie, S., \& Adams, J. (1999). Family orientation in family firms: a model and some empirical evidence. Journal of Small Business and Enterprise Development, 6(1), 55-67. doi:10.1108/EUM0000000006668

Reuber, A. R., \& Fischer, E. (2002). Foreign Sales and Small Firm Growth: The Moderating Role of the Management Team. Entrepreneurship Theory and Practice, 27(1), 29-45. doi:10.1111/15408520.271002

Rose, R. A., \& Stone, S. I. (2011). Instrumental Variable Estimation in Social Work Research: A Technique for Estimating Causal Effects in Nonrandomized Settings. Journal of the Society for Social Work and Research, 2(2), 76-88. doi:10.5243/jsswr.2011.4

Rubini, L., Desmet, K., Piguillem, F., \& Crespo, A. (2012). Breaking down the barriers to firm growth in Europe: the fourth EFIGE policy report. Retrieved from Bruegel:

Salvato, C., \& Melin, L. (2008). Creating Value Across Generations in Family-Controlled Businesses: The Role of Family Social Capital. Family Business Review, 21(3), 259-276.

Sanchez-Bueno, M. J., Muñoz-Bullón, F., \& Galan, J. I. (2019). Socially responsible downsizing: Comparing family and non-family firms. Business Ethics: A European Review. doi:10.1111/beer.12244

Schulze, W. S., Lubatkin, M. H., \& Dino, R. N. (2002). Altruism, agency, and the competitiveness of family firms. Managerial and Decision Economics, 23(4-5), 247-259. doi:10.1002/mde.1064

Schulze, W. S., Lubatkin, M. H., Dino, R. N., \& Buchholtz, A. K. (2001). Agency Relationships in Family Firms: Theory and Evidence. Organization Science, 12(2), 99-116. doi:10.1287/orsc.12.2.99.10114

Sciascia, S., Mazzola, P., \& Chirico, F. (2013). Generational Involvement in the Top Management Team of Family Firms: Exploring Nonlinear Effects on Entrepreneurial Orientation. Entrepreneurship Theory and Practice, 37(1), 69-85. doi:10.1111/j.1540-6520.2012.00528.x

Shepherd, D., \& Wiklund, J. (2009). Are We Comparing Apples With Apples or Apples With Oranges? Appropriateness of Knowledge Accumulation Across Growth Studies. Entrepreneurship Theory and Practice, 33(1), 105-123. doi:10.1111/j.1540-6520.2008.00282.x 
Soleimanof, S., Rutherford, M. W., \& Webb, J. W. (2017). The Intersection of Family Firms and Institutional Contexts: A Review and Agenda for Future Research. Family Business Review, 31(1), 3253. doi:10.1177/0894486517736446

Sraer, D., \& Thesmar, D. (2007). Performance and behavior of family firms Evidence from the French stock market. Journal of the European Economic Association, 5(4), 709-751.

Testa, F., Miroshnychenko, I., Barontini, R., \& Frey, M. (2018). Does it pay to be a greenwasher or a brownwasher? Business Strategy and the Environment, 27(7), 1104-1116.

Unger, J. M., Rauch, A., Frese, M., \& Rosenbusch, N. (2011). Human capital and entrepreneurial success: A meta-analytical review. Journal of Business Venturing, 26(3), 341-358. doi:https://doi.org/10.1016/j.jbusvent.2009.09.004

Villalonga, B., \& Amit, R. (2006). How do family ownership, control and management affect firm value? Journal of Financial Economics, 80(2), 385-417. doi:https://doi.org/10.1016/j.jfineco.2004.12.005

Villalonga, B., \& Amit, R. (2009). How Are U.S. Family Firms Controlled ? Review of Financial Studies, 22(8), 3047-3091.

Villalonga, B., \& Amit, R. (2010). Family Control of Firms and Industries. Financial Management, 39(3), 863-904.

Villalonga, B., Amit, R., Trujillo, M.-A., \& Guzmán, A. (2015). Governance of Family Firms. Annual Review of Financial Economics, 7(1), 635-654. doi:10.1146/annurev-financial-110613-034357

Wagner, D., Block, J. H., Miller, D., Schwens, C., \& Xi, G. (2015). A meta-analysis of the financial performance of family firms. Another attempt. Journal of Family Business Strategy, 6, 3-13.

Wu, Z., Chua, J. H., \& Chrisman, J. J. (2007). Effects of family ownership and management on small business equity financing. Journal of Business Venturing, 22(6), 875-895. doi:https://doi.org/10.1016/j.jbusvent.2006.07.002

Yasuda, T. (2005). Firm Growth, Size, Age and Behavior in Japanese Manufacturing. Small Business Economics, 24(1), 1-15. doi:10.1007/s11187-005-7568-y

Yu, A., Lumpkin, G. T., Sorenson, R. L., \& Brigham, K. H. (2012). The Landscape of Family Business Outcomes. Family Business Review, 25(1), 33-57. doi:10.1177/0894486511430329

Zahra, S. A., Hayton, J. C., \& Salvato, C. (2004). Entrepreneurship in Family vs. Non-Family Firms: A Resource-Based Analysis of the Effect of Organizational Culture. Entrepreneurship Theory and Practice, 28(4), 363-381.

Zahra, S. A., Neubaum, D. O., \& Larrañeta, B. (2007). Knowledge sharing and technological capabilities: The moderating role of family involvement. Journal of Business Research, 60(10), 1070-1079. doi:https://doi.org/10.1016/j.jbusres.2006.12.014 


\section{FOOTNOTES}

i "We have attempted to capture all family firms and their equity holdings. U.S. reporting requirements may cause a downward bias in our estimates of family ownership creating a bias towards zero in our testing. For instance, two great grandchildren of Schlumberger Limited's founder serve on the current board of directors. From 1992 to 1997, the aggregate ownership reported in the proxy statement of these two directors was 1.3 percent. However, in 1998, their aggregate holdings increase to 5 percent because their mother passed away and they inherited an additional 25 million shares that were not previously reported in the proxy statement. The Securities Exchange Act of 1934 only requires that officers and directors and five percent owners report their holdings. Thus, several family members could hold 4.9 percent of the firm, not serve as an officer or director, and we would not capture this as family ownership. This suggests the use of a binary indicator variable to denote family firms." (Anderson \& Reeb, 2003a, p. 1310).

${ }^{\text {ii }}$ Our main results do not change if we estimate our model without the GDP growth proxy to decrease any confounding effects associated with country-level growth.

iii The proxy of family influence in our model is not endogenous according to the Durbin-Watson and WuHausman tests; however, we have re-estimated our explanatory model using the Heckman's two-step treatment effects estimator (Heckman, 1979) with robust standard errors, where the treatment (being a family firm) has been modelled as an endogenous choice in all models. In the endogenous selection equation, family influence is predicted by Market Risk variable (defined as beta) since it affects the choice of ownership structure (Demsetz \& Villalonga, 2001). This variable does not influence firm growth (the correlation between Market Risk and Firm Growth is not statistically different from zero). Quotation Time (the log number of years for which the firm has been listed) has also been included as an external instrument, as it is likely to have an impact on ownership structure, but unlikely to affect growth. In the endogenous selection equation, we also included all controls of our main model. As per our main findings, we documented that family firms have superior growth than non-family firms. However, as the self-selection parameter (Mill's $\lambda$ ) was not different from zero in all the estimated models, the necessity of using the Heckman's two-step treatment effects estimator has been rejected and, thus, the 2SLS estimates are reported in our main analysis.

iv We have also analyzed the growth rates of family and nonfamily firms in fragile and stable countries using the Fragility States Index data. The results of this additional check show that family firms from fragile countries grow more than their nonfamily counterparts only in the presence of high institutional development. We thank one anonymous reviewer for suggesting this analysis.

${ }^{v}$ When ROA is used as a dependent variable in the estimations, we omit the Cash flow variable from the vector of control variables, because these two variables are highly correlated (0.67). We thank one anonymous reviewer for suggesting this insightful specification of our model.

${ }^{\text {vi }}$ Our findings contrast with those from prior studies that found family firms doing well where there is an institutional void (Khanna \& Palepu, 2000), likely because those studies have examined only developing nations rather than the combination of both developed and developing nations within a single research setting. 
Table 1. Sample Distribution by Country

\begin{tabular}{lccc}
\hline Country & Non-family firms \% & Family firms \% & Total sample \% \\
\hline Australia & 3.975 & 2.977 & 3.649 \\
Austria & 0.921 & 0.941 & 0.927 \\
Belgium & 1.305 & 1.795 & 1.465 \\
Brazil & 1.301 & 0.828 & 1.147 \\
Canada & 3.996 & 4.642 & 4.207 \\
Croatia & 0.192 & 0.086 & 0.158 \\
Cyprus & 0.042 & 0.173 & 0.085 \\
Czech Republic & 0.226 & 0.112 & 0.189 \\
Denmark & 1.686 & 0.716 & 1.369 \\
Finland & 2.151 & 0.915 & 1.747 \\
France & 3.305 & 6.541 & 4.362 \\
Germany & 6.038 & 7.171 & 6.408 \\
Greece & 2.130 & 10.406 & 4.832 \\
Hong Kong & 0.967 & 2.778 & 1.558 \\
Hungary & 0.209 & 0.138 & 0.186 \\
India & 0.623 & 3.650 & 1.612 \\
Indonesia & 0.661 & 0.509 & 0.611 \\
Ireland & 0.736 & 0.854 & 0.775 \\
Israel & 0.272 & 0.147 & 0.231 \\
Italy & 2.100 & 5.937 & 3.353 \\
Japan & 6.841 & 1.648 & 5.145 \\
Malaysia & 0.460 & 0.311 & 0.411 \\
Mexico & 0.243 & 0.267 & 0.251 \\
Netherlands & 1.669 & 1.018 & 1.457 \\
New Zealand & 0.356 & 0.181 & 0.299 \\
Norway & 2.356 & 1.691 & 2.139 \\
Philippines & 0.301 & 0.872 & 0.487 \\
Poland & 0.619 & 0.440 & 0.561 \\
Portugal & 0.724 & 0.699 & 0.716 \\
Qatar & 0.218 & 0.000 & 0.147 \\
Romania & 0.130 & 0.164 & 0.141 \\
Russia & 1.603 & 0.475 & 1.234 \\
Singapore & 1.385 & 1.536 & 1.434 \\
Slovenia & 0.238 & 0.500 & 0.324 \\
South Africa & 0.929 & 0.673 & 0.845 \\
South Korea & 0.498 & 0.380 & 0.459 \\
Spain & 1.983 & 2.278 & 2.080 \\
Sweden & 4.243 & 2.200 & 3.576 \\
Switzerland & 2.615 & 2.295 & 2.511 \\
Thailand & 0.757 & 0.759 & 0.758 \\
Turkey & 0.799 & 1.976 & 1.183 \\
USA & 27.669 & 22.159 & 25.870 \\
United Kingdom & 10.527 & $\mathbf{3 2 . 6 6}$ & $\mathbf{1 0 0}$ \\
\hline Total \% & & \\
\hline & & & \\
\hline
\end{tabular}


Table 2. Sample Distribution by Industrial Sector (three-digit ICB codes)

\begin{tabular}{|c|c|c|c|}
\hline Industry & Non-family firms $\%$ & Family firms \% & Total sample \% \\
\hline Aerospace \& Defense & 1.569 & 0.526 & 1.229 \\
\hline Alternative Energy & 0.925 & 1.268 & 1.037 \\
\hline Automobiles \& Parts & 2.1 & 2.632 & 2.274 \\
\hline Beverages & 1.23 & 1.182 & 1.214 \\
\hline Chemicals & 3.996 & 2.347 & 3.457 \\
\hline Construction \& Materials & 5.054 & 6.204 & 5.43 \\
\hline Electricity & 4.176 & 1.018 & 3.145 \\
\hline Electronic \& Electrical Equipment & 4.285 & 3.063 & 3.886 \\
\hline Fixed Line Telecommunications & 1.916 & 0.561 & 1.474 \\
\hline Food \& Drug Retailers & 1.603 & 1.432 & 1.547 \\
\hline Food Producers & 4.054 & 4.953 & 4.348 \\
\hline Forestry \& Paper & 1.113 & 0.233 & 0.826 \\
\hline Gas, Water \& Multiutilities & 2.23 & 0.639 & 1.71 \\
\hline General Industrials & 2.188 & 2.718 & 2.361 \\
\hline General Retailers & 4.259 & 6.489 & 4.987 \\
\hline Health Care Equipment & 3.502 & 4.021 & 3.672 \\
\hline Household Goods \& Home construction & 1.908 & 3.322 & 2.37 \\
\hline Industrial Engineering & 5.661 & 4.677 & 5.34 \\
\hline Industrial Metals \& Mining & 3.142 & 2.977 & 3.088 \\
\hline Industrial Transport & 3.992 & 2.546 & 3.519 \\
\hline Leisure Goods & 1.159 & 1.053 & 1.124 \\
\hline Media & 3.414 & 5.497 & 4.094 \\
\hline Mining & 3.134 & 3.063 & 3.111 \\
\hline Mobile Telecommunications & 1.176 & 1.225 & 1.192 \\
\hline Oil \& Gas Producers & 4.879 & 3.987 & 4.587 \\
\hline Oil Equipment \& Services & 2.87 & 1.881 & 2.547 \\
\hline Personal Goods & 1.649 & 4.755 & 2.663 \\
\hline Pharmaceuticals \& Biotechnology & 3.841 & 4.401 & 4.024 \\
\hline Software \& Computer Services & 4.038 & 7.058 & 5.024 \\
\hline Support Services & 5.259 & 4.91 & 5.145 \\
\hline Technology Hardware \& Equipment & 4.603 & 4.452 & 4.554 \\
\hline Tobacco & 0.548 & 0.138 & 0.414 \\
\hline Travel \& Leisure & 4.519 & 4.772 & 4.601 \\
\hline Total \% & 67.34 & 32.66 & 100 \\
\hline
\end{tabular}


Table 3. Definition of World Governance Indicators (WGIs)

\begin{tabular}{|c|c|}
\hline WGI & Description \\
\hline Democratic Freedom & $\begin{array}{l}\text { Reflects perceptions of the extent to which a country's citizens } \\
\text { can participate in selecting their government, as well as } \\
\text { freedom of expression, freedom of association, and a free } \\
\text { media. It ranges from }-1.212 \text { (lowest democratic freedom) to } \\
1.738 \text { (highest democratic freedom). }\end{array}$ \\
\hline Government Effectiveness & $\begin{array}{l}\text { Reflects perceptions of the quality of public services, the } \\
\text { quality of the civil service, and the degree of its independence } \\
\text { from political pressures, the quality of policy formulation and } \\
\text { implementation, and the credibility of the government's } \\
\text { commitment to such policies. It ranges from - } 0.471 \text { (lowest } \\
\text { government effectiveness) to } 2.437 \text { (highest government } \\
\text { effectiveness). }\end{array}$ \\
\hline Regulatory Quality & $\begin{array}{l}\text { Reflects perceptions of the ability of the government to } \\
\text { formulate and implement sound policies and regulations that } \\
\text { permit and promote private sector development. It ranges from } \\
-0.521 \text { (lowest regulatory quality) to } 2.261 \text { (highest regulatory } \\
\text { quality). }\end{array}$ \\
\hline Rule of Law & $\begin{array}{l}\text { Reflects perceptions of the extent to which agents have } \\
\text { confidence in and abide by the rules of society, and particularly } \\
\text { the quality of contract enforcement, property rights, the police, } \\
\text { the courts, as well as the likelihood of crime and violence. It } \\
\text { ranges from }-0.970 \text { (lowest rule of law) to } 2.100 \text { (highest rule } \\
\text { of law). }\end{array}$ \\
\hline Corruption Control & $\begin{array}{l}\text { Reflects perceptions of the extent to which public power is } \\
\text { exercised for private gain, including both petty and grand forms } \\
\text { of corruption, as well as the "capture" of the state by elites and } \\
\text { private interests. It ranges from - } 1.132 \text { (lowest corruption } \\
\text { control) to } 2.446 \text { (highest corruption control). }\end{array}$ \\
\hline $\begin{array}{l}\text { Political Stability and Absence of } \\
\text { Terrorism (Political Stability) }\end{array}$ & $\begin{array}{l}\text { Reflects perceptions of the likelihood of political instability } \\
\text { and/or politically-motivated violence, including terrorism. It } \\
\text { ranges from }-1.998 \text { (lowest political stability and absence of } \\
\text { terrorism) to } 1.528 \text { (highest political stability and absence of } \\
\text { terrorism). }\end{array}$ \\
\hline
\end{tabular}


Table 4. Descriptive Statistics

\begin{tabular}{|c|c|c|c|c|c|}
\hline & Mean & Median & S.D. & Min. & Max. \\
\hline \multicolumn{6}{|l|}{ Non-family firms } \\
\hline 1 Firm growth & 0.040 & 0.038 & 0.321 & -8.023 & 9.234 \\
\hline 2 Firm size & 15.615 & 15.258 & 2.700 & 7.675 & 26.175 \\
\hline 3 Firm age & 3.819 & 3.970 & 0.951 & 0.000 & 6.215 \\
\hline 4 Financial leverage & 0.252 & 0.240 & 0.179 & 0.000 & 2.943 \\
\hline 5 Cash flow & 0.096 & 0.090 & 0.095 & -2.346 & 1.120 \\
\hline 6 R\&D & 0.013 & 0.000 & 0.040 & 0.000 & 0.968 \\
\hline 7 WGI & 0.098 & 0.189 & 0.948 & -3.550 & 1.289 \\
\hline 8 Democratic freedom & 1.108 & 1.144 & 0.487 & -1.212 & 1.738 \\
\hline 9 Government effectiveness & 1.437 & 1.529 & 0.530 & -0.471 & 2.437 \\
\hline 10 Regulatory quality & 1.357 & 1.461 & 0.505 & -0.521 & 2.261 \\
\hline 11 Rule of law & 1.453 & 1.627 & 0.597 & -0.970 & 2.100 \\
\hline 12 Corruption control & 1.405 & 1.465 & 0.719 & -1.132 & 2.446 \\
\hline 13 Political Stability & 0.625 & 0.643 & 0.529 & -1.998 & 1.528 \\
\hline 14 Trade & 66.643 & 56.468 & 58.929 & 22.106 & 442.620 \\
\hline 15 Inflation & 1.789 & 1.615 & 2.326 & -22.902 & 23.642 \\
\hline 16 GDP growth & 0.853 & 1.019 & 2.354 & -8.998 & 24.377 \\
\hline \multicolumn{6}{|l|}{ Family firms } \\
\hline 1 Firm growth & 0.060 & 0.058 & 0.365 & -5.690 & 10.424 \\
\hline 2 Firm size & 14.509 & 14.185 & 2.628 & 7.448 & 25.158 \\
\hline 3 Firm age & 3.536 & 3.526 & 0.806 & 0.000 & 5.781 \\
\hline 4 Financial leverage & 0.236 & 0.217 & 0.195 & 0.000 & 2.878 \\
\hline 5 Cash flow & 0.095 & 0.089 & 0.116 & -2.690 & 4.020 \\
\hline $6 \mathrm{R} \& \mathrm{D}$ & 0.013 & 0.000 & 0.041 & 0.000 & 0.770 \\
\hline 7 WGI & -0.203 & 0.130 & 1.071 & -3.550 & 1.289 \\
\hline 8 Democratic freedom & 1.037 & 1.110 & 0.458 & -1.212 & 1.738 \\
\hline 9 Government effectiveness & 1.246 & 1.507 & 0.620 & -0.471 & 2.437 \\
\hline 10 Regulatory quality & 1.209 & 1.301 & 0.592 & -0.521 & 2.261 \\
\hline 11 Rule of law & 1.267 & 1.598 & 0.666 & -0.970 & 2.100 \\
\hline 12 Corruption control & 1.147 & 1.385 & 0.827 & -1.132 & 2.446 \\
\hline 13 Political Stability & 0.475 & 0.585 & 0.629 & -1.998 & 1.528 \\
\hline 14 Trade & 74.997 & 57.845 & 73.893 & 22.106 & 442.620 \\
\hline 15 Inflation & 1.835 & 1.615 & 2.081 & -5.205 & 23.642 \\
\hline 16 GDP growth & 0.781 & 0.957 & 2.856 & -8.998 & 24.377 \\
\hline \multicolumn{6}{|l|}{ Total sample } \\
\hline 1 Firm growth & 0.047 & 0.044 & 0.336 & -8.023 & 10.424 \\
\hline 2 Firm size & 15.251 & 14.910 & 2.726 & 7.448 & 26.175 \\
\hline 3 Firm age & 3.726 & 3.784 & 0.915 & 0.000 & 6.215 \\
\hline 4 Financial leverage & 0.247 & 0.233 & 0.184 & 0.000 & 2.943 \\
\hline 5 Cash flow & 0.095 & 0.090 & 0.102 & -2.690 & 4.020 \\
\hline $6 \mathrm{R} \& \mathrm{D}$ & 0.013 & 0.000 & 0.040 & 0.000 & 0.968 \\
\hline 7 WGI & -0.000 & 0.184 & 1.000 & -3.550 & 1.289 \\
\hline 8 Democratic freedom & 1.085 & 1.134 & 0.479 & -1.212 & 1.738 \\
\hline 9 Government effectiveness & 1.374 & 1.524 & 0.568 & -0.471 & 2.437 \\
\hline 10 Regulatory quality & 1.309 & 1.453 & 0.540 & -0.521 & 2.261 \\
\hline 11 Rule of law & 1.392 & 1.616 & 0.626 & -0.970 & 2.100 \\
\hline 12 Corruption control & 1.321 & 1.411 & 0.765 & -1.132 & 2.446 \\
\hline 13 Political Stability & 0.576 & 0.632 & 0.568 & -1.998 & 1.528 \\
\hline 14 Trade & 69.371 & 56.476 & 64.319 & 22.106 & 442.620 \\
\hline 15 Inflation & 1.804 & 1.615 & 2.249 & -22.902 & 23.642 \\
\hline 16 GDP growth & 0.830 & 0.995 & 2.529 & -8.998 & 24.377 \\
\hline
\end{tabular}

Note: All the definitions of variables are provided in the Data section. Industry and time dummies are not shown in the table. 
Table 5. Mean Values of World Governance Indicators by Country

\begin{tabular}{|c|c|c|c|c|c|c|}
\hline Country & $\begin{array}{l}\text { Democratic } \\
\text { Freedom }\end{array}$ & $\begin{array}{l}\text { Government } \\
\text { Effectiveness }\end{array}$ & $\begin{array}{l}\text { Regulatory } \\
\text { Quality }\end{array}$ & $\begin{array}{l}\text { Rule of } \\
\text { Law }\end{array}$ & $\begin{array}{l}\text { Corruption } \\
\text { Control }\end{array}$ & $\begin{array}{l}\text { Political } \\
\text { Stability }\end{array}$ \\
\hline Austria & 1.395 & 1.642 & 1.487 & 1.854 & 1.588 & 1.209 \\
\hline Belgium & 1.356 & 1.510 & 1.282 & 1.425 & 1.559 & 0.760 \\
\hline Brazil & 0.489 & -0.124 & 0.007 & -0.073 & -0.148 & -0.142 \\
\hline Canada & 1.416 & 1.775 & 1.731 & 1.807 & 1.933 & 1.142 \\
\hline Croatia & 0.513 & 0.594 & 0.466 & 0.231 & 0.100 & 0.617 \\
\hline Cyprus & 1.043 & 1.340 & 1.198 & 1.082 & 1.044 & 0.550 \\
\hline Czech Republic & 1.016 & 0.953 & 1.126 & 1.018 & 0.350 & 1.017 \\
\hline Denmark & 1.566 & 1.988 & 1.777 & 1.953 & 2.332 & 0.965 \\
\hline Finland & 1.529 & 2.064 & 1.817 & 1.992 & 2.237 & 1.282 \\
\hline France & 1.213 & 1.437 & 1.180 & 1.457 & 1.407 & 0.423 \\
\hline Germany & 1.363 & 1.619 & 1.605 & 1.697 & 1.791 & 0.852 \\
\hline Greece & 0.815 & 0.478 & 0.635 & 0.585 & 0.009 & -0.010 \\
\hline Hong Kong & 0.528 & 1.802 & 1.989 & 1.645 & 1.732 & 0.996 \\
\hline Hungary & 0.783 & 0.630 & 0.973 & 0.700 & 0.353 & 0.705 \\
\hline India & 0.426 & -0.049 & -0.397 & -0.058 & -0.446 & -1.159 \\
\hline Indonesia & 0.099 & -0.164 & -0.208 & -0.467 & -0.557 & -0.542 \\
\hline Ireland & 1.332 & 1.478 & 1.706 & 1.727 & 1.619 & 0.994 \\
\hline Israel & 0.702 & 1.305 & 1.245 & 1.040 & 0.921 & -1.051 \\
\hline Italy & 1.000 & 0.392 & 0.813 & 0.397 & 0.129 & 0.451 \\
\hline Japan & 1.029 & 1.582 & 1.151 & 1.388 & 1.514 & 0.976 \\
\hline Malaysia & -0.399 & 0.978 & 0.685 & 0.502 & 0.226 & 0.128 \\
\hline Mexico & 0.022 & 0.253 & 0.384 & -0.497 & -0.618 & -0.749 \\
\hline Netherlands & 1.532 & 1.789 & 1.797 & 1.864 & 2.053 & 1.010 \\
\hline New Zealand & 1.548 & 1.849 & 1.923 & 1.936 & 2.298 & 1.443 \\
\hline Norway & 1.660 & 1.872 & 1.596 & 1.966 & 2.194 & 1.254 \\
\hline Philippines & 0.072 & 0.102 & -0.070 & -0.411 & -0.500 & -1.078 \\
\hline Poland & 0.999 & 0.645 & 0.953 & 0.705 & 0.564 & 0.889 \\
\hline Portugal & 1.126 & 1.085 & 0.865 & 1.075 & 1.015 & 0.834 \\
\hline Qatar & -1.079 & 0.901 & 0.667 & 0.862 & 0.995 & 1.071 \\
\hline Romania & 0.434 & -0.224 & 0.592 & 0.084 & -0.161 & 0.197 \\
\hline Russia & -0.984 & -0.339 & -0.376 & -0.804 & -1.018 & -0.895 \\
\hline Singapore & -0.119 & 2.198 & 2.020 & 1.734 & 2.113 & 1.306 \\
\hline Slovenia & 1.020 & 1.044 & 0.723 & 1.014 & 0.884 & 0.975 \\
\hline South Africa & 0.604 & 0.392 & 0.375 & 0.120 & 0.067 & -0.042 \\
\hline South Korea & 0.694 & 1.142 & 0.996 & 1.003 & 0.498 & 0.270 \\
\hline Spain & 1.086 & 1.059 & 1.038 & 1.084 & 0.932 & -0.052 \\
\hline Sweden & 1.587 & 1.905 & 1.808 & 1.978 & 2.239 & 1.100 \\
\hline Switzerland & 1.561 & 1.961 & 1.685 & 1.846 & 2.107 & 1.329 \\
\hline Thailand & -0.705 & 0.288 & 0.235 & -0.131 & -0.401 & -1.075 \\
\hline Turkey & -0.228 & 0.290 & 0.325 & 0.019 & 0.007 & -1.179 \\
\hline USA & 1.115 & 1.514 & 1.368 & 1.613 & 1.349 & 0.558 \\
\hline United Kingdom & 1.301 & 1.596 & 1.748 & 1.737 & 1.720 & 0.417 \\
\hline
\end{tabular}


Table 6. Univariate Tests

Panel A. Mean difference in firm growth by family influence

\begin{tabular}{lcccc} 
& $\begin{array}{c}\text { Family firms (1) } \\
\text { Mean }\end{array}$ & $\begin{array}{c}\text { Non-family firms (2) } \\
\text { Mean }\end{array}$ & $\begin{array}{c}\text { Whole sample } \\
\text { Mean }\end{array}$ & $\begin{array}{c}\text { Difference in means } \\
(1)-(2)\end{array}$ \\
\hline One-year firm growth & 0.060 & 0.040 & 0.047 & $0.020^{* * *}$ \\
Two-year firm growth & 0.102 & 0.069 & 0.080 & $0.032^{* * *}$ \\
Three-year firm growth & 0.162 & 0.117 & 0.132 & $0.045^{* * *}$ \\
\hline
\end{tabular}

$\underline{\text { Panel B. Mean difference by family influence and geographical location }}$

\begin{tabular}{|c|c|c|c|c|}
\hline & $\begin{array}{c}\text { Family firms (1) } \\
\text { Mean }\end{array}$ & $\begin{array}{l}\text { Non-family firms (2) } \\
\text { Mean }\end{array}$ & $\begin{array}{c}\text { Whole sample } \\
\text { Mean }\end{array}$ & $\begin{array}{c}\text { Difference in means } \\
(1)-(2)\end{array}$ \\
\hline \multicolumn{5}{|c|}{ Anglo-Saxon countries } \\
\hline One-year firm growth & 0.093 & 0.051 & 0.062 & $0.042^{* * *}$ \\
\hline Two-year firm growth & 0.173 & 0.089 & 0.111 & $0.084^{* * *}$ \\
\hline Three-year firm growth & 0.263 & 0.139 & 0.170 & $0.124^{* * *}$ \\
\hline \multicolumn{5}{|c|}{ European countries } \\
\hline One-year firm growth & 0.015 & 0.018 & 0.017 & -0.003 \\
\hline Two-year firm growth & 0.011 & 0.030 & 0.023 & -0.019 \\
\hline Three-year firm growth & 0.043 & 0.070 & 0.059 & -0.027 \\
\hline \multicolumn{5}{|c|}{ Asian countries } \\
\hline One-year firm growth & 0.130 & 0.038 & 0.065 & $0.092^{* * *}$ \\
\hline Two-year firm growth & 0.257 & 0.057 & 0.116 & $0.200^{* * *}$ \\
\hline Three-year growth & 0.411 & 0.088 & 0.177 & $0.323^{* * *}$ \\
\hline \multicolumn{5}{|c|}{ Other countries } \\
\hline One-year firm growth & 0.122 & 0.105 & 0.110 & 0.017 \\
\hline Two-year firm growth & 0.225 & 0.203 & 0.209 & 0.022 \\
\hline Three-year firm growth & 0.341 & 0.344 & 0.343 & -0.003 \\
\hline
\end{tabular}

Note. This table presents the independent sample t-tests with unequal variances on equality of means of the firm growth by family influence (Panel A) and mean firm growth by country and family influence (Panel B). Family firms are defined as those where the founder or descendant or family member is director or large shareholder. One-year firm growth is the log-difference of net sales for company $i$ from country $c$ between time $t$ and $t$ - 1 . Two-year firm growth is the log-difference of net sales for company $i$ from country $c$ between time $t$ and $t-2$. Three-year firm growth is the log-difference of net sales for company $i$ from country $c$ between time $t$ and $t$-3. Anglo-Saxon countries are the following: Australia, Canada, UK, USA and New Zealand. European countries are the following: Austria, Belgium, Croatia, Cyprus, Czech Republic, Denmark, Finland, France, Germany, Greece, Hungary, Ireland, Italy, Netherlands, Norway, Poland, Portugal, Romania, Slovenia, Spain, Sweden and Switzerland. Asian countries are the following: Hong-Kong, India, Indonesia, Japan, Malaysia, Philippines, Singapore, South Korea and Thailand. Other countries are the following: Brazil, Israel, Mexico, Qatar, Russia, South Africa and Turkey. $+\mathrm{p}<0.10, * \mathrm{p}<0.05, * * \mathrm{p}<0.01, * * * \mathrm{p}<0.001$ 
Table 7. Correlation Matrix

\begin{tabular}{|c|c|c|c|c|c|c|c|c|c|}
\hline & 1 & 2 & 3 & 4 & 5 & 6 & 7 & 8 & 9 \\
\hline 1 Family & 1.000 & & & & & & & & \\
\hline 2 Firm growth & $0.028 * * *$ & 1.000 & & & & & & & \\
\hline 3 Firm size & $-0.191 * * *$ & $0.045^{* * * *}$ & 1.000 & & & & & & \\
\hline 5 Financial leverage & $-0.040 * * *$ & $-0.036 * * *$ & $0.137 * * *$ & $0.034 * * *$ & 1.000 & & & & \\
\hline 6 Cash flow & -0.004 & $0.135 * * *$ & $0.096 * * *$ & -0.003 & $-0.183 * * *$ & 1.000 & & & \\
\hline 7 R\&D & -0.005 & -0.003 & $-0.114 * * *$ & $-0.051 * * *$ & $-0.179 * * *$ & $-0.078 * * *$ & 1.000 & & \\
\hline 10 Government effectiveness & $-0.158 * * *$ & -0.008 & $-0.113 * * *$ & $0.073 * * *$ & $-0.118 * * *$ & $0.022 * * *$ & $0.117 * * *$ & $0.962 * * *$ & $0.673^{* * *}$ \\
\hline 11 Regulatory quality & $-0.128 * * *$ & -0.004 & $-0.269 * * *$ & $0.025 * * *$ & $-0.120 * * *$ & 0.008 & $0.077 * * *$ & $0.949 * * *$ & $0.694 * * *$ \\
\hline 12 Rule of law & $-0.139 * * *$ & -0.012 & $-0.216 * * *$ & $0.066^{* * *}$ & $-0.116^{* * *}$ & $0.013 *$ & $0.112 * * *$ & $0.977 * * *$ & $0.780 * * *$ \\
\hline 13 Corruption control & $-0.158 * * *$ & 0.001 & $-0.131 * * *$ & $0.062 * * *$ & $-0.117 * * *$ & 0.010 & $0.106 * * *$ & $0.975 * * *$ & $0.741 * * *$ \\
\hline 14 Political stability & $-0.124 * * *$ & $-0.024 * * *$ & $-0.118 * * *$ & $0.037 * * *$ & $-0.079 * * *$ & $-0.041 * * *$ & $0.095 * * *$ & $0.874 * * *$ & $0.673 * * *$ \\
\hline 15 Trade & $0.061^{* * *}$ & $0.026 * * *$ & $-0.012+$ & $-0.067 * * *$ & $-0.023 * * *$ & $-0.044 * * *$ & $-0.043 * * *$ & $0.157 * * *$ & $-0.194 * * *$ \\
\hline
\end{tabular}

\begin{tabular}{|c|c|c|c|c|c|c|c|c|}
\hline & 10 & 11 & 12 & 13 & 14 & 15 & 16 & 17 \\
\hline 10 Government effectiveness & 1.000 & & & & & & & \\
\hline 11 Regulatory quality & $0.921 * * *$ & 1.000 & & & & & & \\
\hline 12 Rule of law & $0.959 * * *$ & $0.934 * * *$ & 1.000 & & & & & \\
\hline 13 Corruption control & $0.962 * * *$ & $0.923 * * *$ & $0.954 * * *$ & 1.000 & & & & \\
\hline 14 Political stability & $0.807 * * *$ & $0.780 * * *$ & $0.790 * * *$ & $0.820 * * *$ & 1.000 & & & \\
\hline 15 Trade & $0.214 * * *$ & $0.262 * * *$ & $0.102 * * *$ & $0.198 * * *$ & $0.252 * * *$ & 1.000 & & \\
\hline 16 Inflation & $-0.420 * * *$ & $-0.391 * * *$ & $-0.433 * * *$ & $-0.384 * * *$ & $-0.417 * * *$ & $-0.039 * * *$ & 1.000 & \\
\hline 17 GDP growth & $-0.023 * * *$ & $-0.059 * * *$ & $-0.050 * * *$ & -0.003 & $-0.064 * * *$ & $0.125 * * *$ & $0.239 * * *$ & 1.000 \\
\hline
\end{tabular}

Note: All the definitions of variables are provided in the Data section. Industry and time dummies are not shown in the table. $+\mathrm{p}<0.10, * \mathrm{p}<0.05, * * \mathrm{p}<0.01, * * * \mathrm{p}<0.001$ 
Table 8. Main Results

\begin{tabular}{|c|c|c|c|c|c|c|c|c|c|}
\hline $\begin{array}{l}\text { Model } \\
\text { D.V.: Firm growth }\end{array}$ & $(1)$ & (2) & (3) & (4) & $(5)$ & (6) & (7) & (8) & (9) \\
\hline Firm size & $\begin{array}{c}0.001 \\
(0.439)\end{array}$ & $\begin{array}{c}0.001 \\
(0.171)\end{array}$ & $\begin{array}{c}0.001 \\
(0.249)\end{array}$ & $\begin{array}{c}0.001 \\
(0.273)\end{array}$ & $\begin{array}{c}0.001 \\
(0.362)\end{array}$ & $\begin{array}{c}0.002 \\
(0.121)\end{array}$ & $\begin{array}{c}0.001 \\
(0.191)\end{array}$ & $\begin{array}{c}0.001 \\
(0.329)\end{array}$ & $\begin{array}{c}0.001 \\
(0.406)\end{array}$ \\
\hline Cash flow & $\begin{array}{l}-0.142 \\
(0.135)\end{array}$ & $\begin{array}{l}-0.153 \\
(0.108)\end{array}$ & $\begin{array}{l}-0.159 \\
(0.097)\end{array}$ & $\begin{array}{l}-0.149 \\
(0.118)\end{array}$ & $\begin{array}{l}-0.161 \\
(0.092)\end{array}$ & $\begin{array}{l}-0.160 \\
(0.094)\end{array}$ & $\begin{array}{l}-0.164 \\
(0.088)\end{array}$ & $\begin{array}{l}-0.161 \\
(0.093)\end{array}$ & $\begin{array}{l}-0.149 \\
(0.117)\end{array}$ \\
\hline$R \& D$ & $\begin{array}{c}0.081 \\
(0.628)\end{array}$ & $\begin{array}{c}0.045 \\
(0.790)\end{array}$ & $\begin{array}{c}0.036 \\
(0.830)\end{array}$ & $\begin{array}{c}0.065 \\
(0.697)\end{array}$ & $\begin{array}{c}0.029 \\
(0.862)\end{array}$ & $\begin{array}{c}0.038 \\
(0.823)\end{array}$ & $\begin{array}{c}0.029 \\
(0.864)\end{array}$ & $\begin{array}{c}0.029 \\
(0.862)\end{array}$ & $\begin{array}{c}0.062 \\
(0.711)\end{array}$ \\
\hline Firm age & $\begin{array}{l}-0.019 \\
(0.000)\end{array}$ & $\begin{array}{l}-0.020 \\
(0.000)\end{array}$ & $\begin{array}{l}-0.019 \\
(0.000)\end{array}$ & $\begin{array}{l}-0.019 \\
(0.000)\end{array}$ & $\begin{array}{l}-0.019 \\
(0.000)\end{array}$ & $\begin{array}{l}-0.019 \\
(0.000)\end{array}$ & $\begin{array}{l}-0.020 \\
(0.000)\end{array}$ & $\begin{array}{l}-0.019 \\
(0.000)\end{array}$ & $\begin{array}{l}-0.019 \\
(0.000)\end{array}$ \\
\hline Leverage & $\begin{array}{l}-0.070 \\
(0.001)\end{array}$ & $\begin{array}{l}-0.066 \\
(0.002)\end{array}$ & $\begin{array}{l}-0.064 \\
(0.003)\end{array}$ & $\begin{array}{l}-0.067 \\
(0.002)\end{array}$ & $\begin{array}{l}-0.064 \\
(0.003)\end{array}$ & $\begin{array}{l}-0.064 \\
(0.003)\end{array}$ & $\begin{array}{l}-0.064 \\
(0.003)\end{array}$ & $\begin{array}{l}-0.063 \\
(0.004)\end{array}$ & $\begin{array}{l}-0.067 \\
(0.002)\end{array}$ \\
\hline GDP growth & $\begin{array}{c}0.011 \\
(0.000)\end{array}$ & $\begin{array}{c}0.011 \\
(0.000)\end{array}$ & $\begin{array}{c}0.011 \\
(0.000)\end{array}$ & $\begin{array}{c}0.011 \\
(0.000)\end{array}$ & $\begin{array}{c}0.010 \\
(0.000)\end{array}$ & $\begin{array}{c}0.011 \\
(0.000)\end{array}$ & $\begin{array}{c}0.010 \\
(0.000)\end{array}$ & $\begin{array}{c}0.010 \\
(0.000)\end{array}$ & $\begin{array}{c}0.011 \\
(0.000)\end{array}$ \\
\hline Inflation & $\begin{array}{c}0.008 \\
(0.000)\end{array}$ & $\begin{array}{c}0.011 \\
(0.000)\end{array}$ & $\begin{array}{c}0.010 \\
(0.000)\end{array}$ & $\begin{array}{c}0.009 \\
(0.000)\end{array}$ & $\begin{array}{c}0.010 \\
(0.000)\end{array}$ & $\begin{array}{c}0.010 \\
(0.000)\end{array}$ & $\begin{array}{c}0.011 \\
(0.000)\end{array}$ & $\begin{array}{c}0.010 \\
(0.000)\end{array}$ & $\begin{array}{c}0.009 \\
(0.000)\end{array}$ \\
\hline Trade & $\begin{array}{c}0.000 \\
(0.783)\end{array}$ & $\begin{array}{l}-0.000 \\
(0.759)\end{array}$ & $\begin{array}{l}-0.000 \\
(0.701)\end{array}$ & $\begin{array}{c}0.000 \\
(0.570)\end{array}$ & $\begin{array}{l}-0.000 \\
(0.549)\end{array}$ & $\begin{array}{l}-0.000 \\
(0.364)\end{array}$ & $\begin{array}{l}-0.000 \\
(0.779)\end{array}$ & $\begin{array}{l}-0.000 \\
(0.603)\end{array}$ & $\begin{array}{l}-0.000 \\
(0.885)\end{array}$ \\
\hline Family & $\begin{array}{c}0.013 \\
(0.011)\end{array}$ & $\begin{array}{c}0.017 \\
(0.001)\end{array}$ & $\begin{array}{c}0.019 \\
(0.001)\end{array}$ & $\begin{array}{c}0.015 \\
(0.005)\end{array}$ & $\begin{array}{c}0.020 \\
(0.000)\end{array}$ & $\begin{array}{c}0.020 \\
(0.000)\end{array}$ & $\begin{array}{c}0.020 \\
(0.000)\end{array}$ & $\begin{array}{c}0.020 \\
(0.000)\end{array}$ & $\begin{array}{c}0.016 \\
(0.003)\end{array}$ \\
\hline WGI & & $\begin{array}{c}0.011 \\
(0.001)\end{array}$ & $\begin{array}{c}0.005 \\
(0.186)\end{array}$ & & & & & & \\
\hline Family $x \mathrm{WGI}_{\mathrm{c}}$ & & & $\begin{array}{c}0.015 \\
(0.004)\end{array}$ & & & & & & \\
\hline $\mathrm{DF}_{\mathrm{c}}$ & & & & $\begin{array}{c}0.003 \\
(0.665)\end{array}$ & & & & & \\
\hline Family x DF & & & & $\begin{array}{c}0.022 \\
(0.041)\end{array}$ & & & & & \\
\hline $\mathrm{GE}_{\mathrm{c}}$ & & & & & $\begin{array}{c}0.010 \\
(0.122)\end{array}$ & & & & \\
\hline Family $x \mathrm{GE}_{\mathrm{c}}$ & & & & & $\begin{array}{c}0.026 \\
(0.003)\end{array}$ & & & & \\
\hline $\mathrm{RQ}_{\mathrm{c}}$ & & & & & & $\begin{array}{c}0.015 \\
(0.047)\end{array}$ & & & \\
\hline Family $x R_{c}$ & & & & & & $\begin{array}{c}0.022 \\
(0.020)\end{array}$ & & & \\
\hline RL & & & & & & & $\begin{array}{c}0.012 \\
(0.044)\end{array}$ & & \\
\hline Family $x \mathrm{RL}_{\mathrm{c}}$ & & & & & & & $\begin{array}{c}0.023 \\
(0.004)\end{array}$ & & \\
\hline $\mathrm{CC}_{\mathrm{c}}$ & & & & & & & & $\begin{array}{c}0.006 \\
(0.203)\end{array}$ & \\
\hline Family x $\mathrm{CC}_{\mathrm{c}}$ & & & & & & & & $\begin{array}{c}0.022 \\
(0.001)\end{array}$ & \\
\hline $\mathrm{PS}_{\mathrm{c}}$ & & & & & & & & & $\begin{array}{l}-0.002 \\
(0.729)\end{array}$ \\
\hline Family x $\mathrm{PS}_{\mathrm{c}}$ & & & & & & & & & $\begin{array}{c}0.023 \\
(0.004)\end{array}$ \\
\hline Industry and year dummies & Yes & Yes & Yes & Yes & Yes & Yes & Yes & Yes & Yes \\
\hline $\mathrm{Z}_{1}$ (p-value) & 0.000 & 0.000 & 0.000 & 0.000 & 0.000 & 0.000 & 0.000 & 0.000 & 0.000 \\
\hline $\mathrm{Z}_{2}$ (p-value) & 0.000 & 0.000 & 0.000 & 0.000 & 0.000 & 0.000 & 0.000 & 0.000 & 0.000 \\
\hline $\mathrm{Z}_{3}$ (p-value) & 0.000 & 0.000 & 0.000 & 0.000 & 0.000 & 0.000 & 0.000 & 0.000 & 0.000 \\
\hline $\mathrm{Z}_{4}$ (p-value) & 0.000 & 0.000 & 0.000 & 0.000 & 0.000 & 0.000 & 0.000 & 0.000 & 0.000 \\
\hline $\mathrm{Z}_{5}$ (p-value) & 0.807 & 0.810 & 0.808 & 0.813 & 0.807 & 0.808 & 0.809 & 0.808 & 0.803 \\
\hline Constant & $\begin{array}{c}0.093 \\
(0.000)\end{array}$ & $\begin{array}{c}0.087 \\
(0.001)\end{array}$ & $\begin{array}{c}0.089 \\
(0.001)\end{array}$ & $\begin{array}{c}0.087 \\
(0.001) \\
\end{array}$ & $\begin{array}{c}0.094 \\
(0.000) \\
\end{array}$ & $\begin{array}{c}0.083 \\
(0.001) \\
\end{array}$ & $\begin{array}{c}0.086 \\
(0.001)\end{array}$ & $\begin{array}{c}0.094 \\
(0.000) \\
\end{array}$ & $\begin{array}{c}0.092 \\
(0.000) \\
\end{array}$ \\
\hline Adjusted $R^{2}$ & 0.033 & 0.033 & 0.033 & 0.032 & 0.032 & 0.033 & 0.033 & 0.033 & 0.032 \\
\hline
\end{tabular}

Notes: This table presents the coefficients and p-values (in parentheses) using the 2SLS regressions with HAC standard errors. $N=15,393$. WGI is the mean-centered WGI variable. $\mathrm{DF}_{c}$ is the mean-centered Democratic Freedom variable. GE $\mathrm{GE}_{\mathrm{c}}$ is the mean-centered Government Effectiveness variable. $\mathrm{RQ}_{\mathrm{c}}$ is the mean-centered Regulatory Quality variable. $\mathrm{RL}_{\mathrm{c}}$ is the mean-centered Rule of Law variable. CC $\mathrm{C}_{\mathrm{c}}$ is the mean-centered Corruption Control variable. $\mathrm{PS}_{\mathrm{c}}$ is the mean-centered Political Stability variable. Endogenous variables are the following: Firm size, R\&D and Cash flow. Instrumental variables are the following: the second-year lagged values of Firm size and R\&D, and both the first- and the second-year lagged values of Cash flow. All the definitions of variables are provided in the Data section. $Z_{1}$ is a Wald test of the joint significance of the reported coefficient. $Z_{2}$ is a Wsald test of the joint significance of the industry dummies. $Z_{3}$ is a Wald test of the joint significance of the year dummies. $Z_{4}$ is a Kleibergen-Paap rk LM statistic. $Z_{5}$ is a Hansen's J statistic. 
Table 9. Post-Hoc Analysis

\begin{tabular}{|c|c|c|c|c|c|c|c|c|c|c|}
\hline $\begin{array}{l}\text { Model } \\
\text { D.V.: Firm growth }\end{array}$ & (1) & (2) & (3) & (4) & (5) & (6) & (7) & (8) & (9) & (10) \\
\hline & \multicolumn{2}{|c|}{ Whole sample } & \multicolumn{2}{|c|}{$\begin{array}{l}\text { Low industry } \\
\text { concentration }\end{array}$} & \multicolumn{2}{|c|}{$\begin{array}{l}\text { High industry } \\
\text { concentration }\end{array}$} & \multicolumn{2}{|c|}{$\begin{array}{c}\text { Financial crisis } \\
\text { period: } 2007-2010\end{array}$} & \multicolumn{2}{|c|}{$\begin{array}{l}\text { Normal economic } \\
\text { period: } 2011-2016\end{array}$} \\
\hline Family & & & $\begin{array}{c}0.018 \\
(0.026)\end{array}$ & $\begin{array}{c}0.019 \\
(0.015)\end{array}$ & $\begin{array}{c}0.017 \\
(0.010)\end{array}$ & $\begin{array}{c}0.019 \\
(0.006)\end{array}$ & $\begin{array}{l}-0.001 \\
(0.889)\end{array}$ & $\begin{array}{c}0.003 \\
(0.748)\end{array}$ & $\begin{array}{c}0.023 \\
(0.001)\end{array}$ & $\begin{array}{c}0.024 \\
(0.001)\end{array}$ \\
\hline WGI & $\begin{array}{c}0.010 \\
(0.002)\end{array}$ & $\begin{array}{c}0.007 \\
(0.031)\end{array}$ & $\begin{array}{c}0.004 \\
(0.437)\end{array}$ & $\begin{array}{l}-0.003 \\
(0.639)\end{array}$ & $\begin{array}{c}0.013 \\
(0.001)\end{array}$ & $\begin{array}{c}0.007 \\
(0.090)\end{array}$ & $\begin{array}{c}0.028 \\
(0.003)\end{array}$ & $\begin{array}{l}0.013 \\
(0.181)\end{array}$ & $\begin{array}{l}0.008 \\
(0.027)\end{array}$ & $\begin{array}{c}0.004 \\
(0.420)\end{array}$ \\
\hline Family $x$ WGI & & & & $\begin{array}{c}0.018 \\
(0.087)\end{array}$ & & $\begin{array}{c}0.013 \\
(0.018)\end{array}$ & & $\begin{array}{c}0.048 \\
(0.000)\end{array}$ & & $\begin{array}{c}0.010 \\
(0.090)\end{array}$ \\
\hline Founder CEO & $\begin{array}{c}0.016 \\
(0.089)\end{array}$ & $\begin{array}{c}0.016 \\
(0.098)\end{array}$ & & & & & & & & \\
\hline Founder non-executive & $\begin{array}{c}0.023 \\
(0.067)\end{array}$ & $\begin{array}{c}0.026 \\
(0.069)\end{array}$ & & & & & & & & \\
\hline Descendant CEO & $\begin{array}{l}-0.004 \\
(0.630)\end{array}$ & $\begin{array}{l}-0.004 \\
(0.639)\end{array}$ & & & & & & & & \\
\hline Descendant non-executive & $\begin{array}{c}0.013 \\
(0.221)\end{array}$ & $\begin{array}{c}0.024 \\
(0.097)\end{array}$ & & & & & & & & \\
\hline Founder CEO x WGI $\mathrm{W}_{\mathrm{c}}$ & & $\begin{array}{c}0.004 \\
(0.639)\end{array}$ & & & & & & & & \\
\hline Founder non-executive $\mathrm{x}$ WGI $\mathrm{c}$ & & $\begin{array}{c}0.008 \\
(0.479)\end{array}$ & & & & & & & & \\
\hline Descendant CEO $\mathrm{x} \mathrm{WGI}_{\mathrm{c}}$ & & $\begin{array}{c}0.004 \\
(0.681)\end{array}$ & & & & & & & & \\
\hline Descendant non-executive $\mathrm{x} \mathrm{WGI}_{\mathrm{c}}$ & & $\begin{array}{c}0.017 \\
(0.097)\end{array}$ & & & & & & & & \\
\hline Controls (as in Table 8) & Yes & Yes & Yes & Yes & Yes & Yes & Yes & Yes & Yes & Yes \\
\hline Industry and year dummies & Yes & Yes & Yes & Yes & Yes & Yes & Yes & Yes & Yes & Yes \\
\hline Constant & $\begin{array}{c}0.090 \\
(0.000)\end{array}$ & $\begin{array}{c}0.090 \\
(0.000)\end{array}$ & $\begin{array}{l}-0.050 \\
(0.297)\end{array}$ & $\begin{array}{l}-0.047 \\
(0.329)\end{array}$ & $\begin{array}{c}0.264 \\
(0.000)\end{array}$ & $\begin{array}{c}0.267 \\
(0.000)\end{array}$ & $\begin{array}{c}0.221 \\
(0.000)\end{array}$ & $\begin{array}{l}0.238 \\
(0.000)\end{array}$ & $\begin{array}{l}0.065 \\
(0.049)\end{array}$ & $\begin{array}{c}0.067 \\
(0.044)\end{array}$ \\
\hline$N$ & 15,393 & 15,393 & 4,126 & 4,126 & 11,267 & 11,267 & 4,081 & 4,081 & 9,199 & 9,199 \\
\hline Adjusted $R^{2}$ & 0.033 & 0.032 & 0.060 & 0.061 & 0.030 & 0.029 & 0.075 & 0.074 & 0.002 & 0.001 \\
\hline
\end{tabular}

Notes: This table presents the coefficients and p-values (in parentheses) using the 2SLS regressions with HAC standard errors. Firm growth is the log-difference of net sales for company $i$ from country $c$ between time $t$ and $t-1$. Family is the dummy variable that equals one if 1 if the founder or descendant or family member is director or large shareholder, zero otherwise. WGI is the mean-centered WGI index. Founder CEO is the dummy variable that equals one if the founder holds a CEO role, zero otherwise. Founder non-executive is the dummy variable that equals one if the founder holds a non-executive role, zero otherwise. Descendant CEO is the dummy variable that equals one if the descendant holds a CEO role, zero otherwise. Descendant non-executive is the dummy variable that equals one if the descendant holds a non-executive role, zero otherwise. Control variables are the following: Firm size, Cash flow, R\&D, Firm age, Leverage, GDP growth, Inflation and Trade. All the definitions of control variables are provided in the Data section. Endogenous variables are the following: Firm size, R\&D and Cash flow. Instrumental variables are the following: the second-year lagged values of Firm size and R\&D, and both the first- and the second-year lagged values of Cash flow. 
Table 10. Robustness Tests

Panel A. Alternative definitions

\begin{tabular}{|c|c|c|c|c|c|c|c|c|c|c|}
\hline \multirow{3}{*}{$\begin{array}{l}\text { Model } \\
\text { D.V.: } \\
\text { Family }\end{array}$} & (1) & (2) & (3) & (4) & (5) & (6) & (7) & (8) & \multirow{2}{*}{\multicolumn{2}{|c|}{$\begin{array}{l}(9) \quad(10) \\
\text { Absolute growth } \\
\text { in net sales }\end{array}$}} \\
\hline & \multicolumn{2}{|c|}{$\begin{array}{l}\text { Absolute growth } \\
\text { in total assets }\end{array}$} & \multicolumn{2}{|c|}{$\begin{array}{l}\text { Relative growth } \\
\text { in total assets }\end{array}$} & \multicolumn{2}{|c|}{$\begin{array}{l}\text { Relative growth } \\
\text { in net sales }\end{array}$} & \multicolumn{2}{|c|}{$\begin{array}{c}\text { Return on } \\
\text { assets }\end{array}$} & & \\
\hline & $\begin{array}{c}0.017 \\
(0.000)\end{array}$ & $\begin{array}{l}0.018 \\
(0.000)\end{array}$ & $\begin{array}{c}0.001 \\
(0.000)\end{array}$ & $\begin{array}{c}0.001 \\
(0.000)\end{array}$ & $\begin{array}{c}0.001 \\
(0.273)\end{array}$ & $\begin{array}{c}0.001 \\
(0.161)\end{array}$ & $\begin{array}{c}0.007 \\
(0.000)\end{array}$ & $\begin{array}{c}0.007 \\
(0.000)\end{array}$ & & \\
\hline Family (>5\%) & & & & & & & & & $\begin{array}{c}0.016 \\
(0.003)\end{array}$ & $\begin{array}{r}0.018 \\
(0.002)\end{array}$ \\
\hline WGI & $\begin{array}{l}-0.003 \\
(0.278)\end{array}$ & $\begin{array}{l}-0.005 \\
(0.105)\end{array}$ & $\begin{array}{c}0.000 \\
(0.699)\end{array}$ & $\begin{array}{l}-0.000 \\
(0.245)\end{array}$ & $\begin{array}{c}0.001 \\
(0.003)\end{array}$ & $\begin{array}{c}0.000 \\
(0.380)\end{array}$ & $\begin{array}{c}0.002 \\
(0.020)\end{array}$ & $\begin{array}{c}0.001 \\
(0.297)\end{array}$ & $\begin{array}{c}0.011 \\
(0.001)\end{array}$ & $\begin{array}{r}0.005 \\
(0.164)\end{array}$ \\
\hline Family x WGI & & $\begin{array}{c}0.007 \\
(0.119)\end{array}$ & & $\begin{array}{c}0.001 \\
(0.009)\end{array}$ & & $\begin{array}{c}0.002 \\
(0.004)\end{array}$ & & $\begin{array}{c}0.002 \\
(0.153)\end{array}$ & & \\
\hline Family $(>5 \%) \times W I_{c}$ & & & & & & & & & & $\begin{array}{r}0.014 \\
(0.005)\end{array}$ \\
\hline Controls (as in Table 8) & Yes & Yes & Yes & Yes & Yes & Yes & Yes & Yes & Yes & Yes \\
\hline Industry and year dummies & Yes & Yes & Yes & Yes & Yes & Yes & Yes & Yes & Yes & Yes \\
\hline Constant & $\begin{array}{l}-0.009 \\
(0.611)\end{array}$ & $\begin{array}{l}-0.008 \\
(0.655)\end{array}$ & $\begin{array}{c}1.002 \\
(0.000)\end{array}$ & $\begin{array}{c}1.002 \\
(0.000)\end{array}$ & $\begin{array}{l}1.011 \\
(0.000)\end{array}$ & $\begin{array}{c}1.011 \\
(0.000)\end{array}$ & $\begin{array}{c}0.018 \\
(0.017)\end{array}$ & $\begin{array}{c}0.018 \\
(0.015)\end{array}$ & $\begin{array}{c}0.087 \\
(0.001)\end{array}$ & $\begin{array}{r}0.089 \\
(0.001)\end{array}$ \\
\hline$N$ & 15461 & 15461 & 15461 & 15461 & 15393 & 15393 & 15350 & 15350 & 15392 & 15392 \\
\hline Adjusted $R^{2}$ & 0.033 & 0.033 & 0.040 & 0.041 & -0.003 & -0.003 & 0.135 & 0.135 & 0.033 & 0.033 \\
\hline
\end{tabular}

Notes: This table presents the coefficients and p-values (in parentheses) using the 2SLS regressions with HAC standard errors. Absolute growth in total assets is the log-difference of total assets for company $i$ from country $c$ between time $t$ and $t-1$. Relative growth in total assets is the ratio of logarithms of total assets for company $i$ from country $c$ in time $t$ and $t-1$. Relative growth in net sales is the ratio of logarithms of net sales for company $i$ from country $c$ in time $t$ and $t$ - 1 . Return on assets is the ratio between earnings before interest, taxes, depreciation and amortization divided by total assets for company $i$ from country $c$. Family is the dummy variable that equals one if 1 if the founder or descendant or family member is director or large shareholder, zero otherwise. Family $(>5 \%)$ is the dummy variable that equals one if the founder or descendant or family member is director or large shareholder owning more than $5 \%$ of the firm's equity, zero otherwise. WGI $_{c}$ is the mean-centered WGI index. Control variables are the following: Firm size, Cash flow, R\&D, Firm age, Leverage, GDP growth, Inflation and Trade (except Models 7 and 8 , where we omit Cash flow). All the definitions of control variables are provided in the Data section. Endogenous variables are the following: Firm size, R\&D and Cash flow (except Models 7 and 8, where Cash flow is omitted). Instrumental variables are the following: the second-year lagged values of Firm size and R\&D, and both the first- and the second-year lagged values of Cash flow (except Models 7 and 8, where we use the first- and the second-year lagged values of R\&D, and the second-year lagged values of Firm size). 
Table 10. Robustness Tests (Cont.)

Panel B. Additional control variables

\begin{tabular}{|c|c|c|c|c|c|c|c|c|c|c|c|c|}
\hline $\begin{array}{l}\text { Model } \\
\text { D.V.: Firm growth }\end{array}$ & (1) & (2) & (3) & (4) & (5) & (6) & (7) & (8) & (9) & (10) & (11) & (12) \\
\hline Family & $\begin{array}{c}0.017 \\
(0.001)\end{array}$ & $\begin{array}{c}0.019 \\
(0.001)\end{array}$ & $\begin{array}{c}0.017 \\
(0.001)\end{array}$ & $\begin{array}{c}0.019 \\
(0.001)\end{array}$ & $\begin{array}{c}0.017 \\
(0.002)\end{array}$ & $\begin{array}{c}0.018 \\
(0.001)\end{array}$ & $\begin{array}{c}0.021 \\
(0.000)\end{array}$ & $\begin{array}{c}0.022 \\
(0.000)\end{array}$ & $\begin{array}{c}0.017 \\
(0.002)\end{array}$ & $\begin{array}{c}0.019 \\
(0.001)\end{array}$ & $\begin{array}{c}0.020 \\
(0.000)\end{array}$ & $\begin{array}{c}0.020 \\
(0.000)\end{array}$ \\
\hline WGI & $\begin{array}{c}0.011 \\
(0.001)\end{array}$ & $\begin{array}{l}0.005 \\
(0.186)\end{array}$ & $\begin{array}{c}0.012 \\
(0.000)\end{array}$ & $\begin{array}{c}0.005 \\
(0.164)\end{array}$ & $\begin{array}{c}0.011 \\
(0.001)\end{array}$ & $\begin{array}{c}0.004 \\
(0.311)\end{array}$ & $\begin{array}{c}0.008 \\
(0.010)\end{array}$ & $\begin{array}{c}0.003 \\
(0.398)\end{array}$ & $\begin{array}{c}0.014 \\
(0.000)\end{array}$ & $\begin{array}{c}0.009 \\
(0.018)\end{array}$ & $\begin{array}{c}0.012 \\
(0.000)\end{array}$ & $\begin{array}{c}0.005 \\
(0.103)\end{array}$ \\
\hline Family x WGI & & $\begin{array}{c}0.015 \\
(0.004)\end{array}$ & & $\begin{array}{c}0.016 \\
(0.002)\end{array}$ & & $\begin{array}{c}0.020 \\
(0.001)\end{array}$ & & $\begin{array}{c}0.013 \\
(0.009)\end{array}$ & & $\begin{array}{c}0.013 \\
(0.009)\end{array}$ & & $\begin{array}{c}0.017 \\
(0.003)\end{array}$ \\
\hline Industry concentration & $\begin{array}{l}-0.022 \\
(0.686)\end{array}$ & $\begin{array}{l}-0.022 \\
(0.692)\end{array}$ & & & & & & & & & $\begin{array}{l}-0.041 \\
(0.451)\end{array}$ & $\begin{array}{l}-0.041 \\
(0.451)\end{array}$ \\
\hline Innovation output & & & $\begin{array}{l}-0.162 \\
(0.105)\end{array}$ & $\begin{array}{c}-0.162 \\
(0.104)\end{array}$ & & & & & & & $\begin{array}{l}-0.180 \\
(0.093)\end{array}$ & $\begin{array}{l}-0.180 \\
(0.092)\end{array}$ \\
\hline Public spending & & & & & $\begin{array}{l}-0.001 \\
(0.023)\end{array}$ & $\begin{array}{l}-0.001 \\
(0.038)\end{array}$ & & & & & $\begin{array}{l}-0.000 \\
(0.418)\end{array}$ & $\begin{array}{l}-0.000 \\
(0.430)\end{array}$ \\
\hline Internationalization & & & & & & & $\begin{array}{c}0.001 \\
(0.708)\end{array}$ & $\begin{array}{c}0.001 \\
(0.720)\end{array}$ & & & $\begin{array}{c}0.001 \\
(0.660)\end{array}$ & $\begin{array}{c}0.001 \\
(0.684)\end{array}$ \\
\hline Population size & & & & & & & & & $\begin{array}{c}0.013 \\
(0.000)\end{array}$ & $\begin{array}{c}0.012 \\
(0.000)\end{array}$ & $\begin{array}{c}0.009 \\
(0.001)\end{array}$ & $\begin{array}{c}0.008 \\
(0.004)\end{array}$ \\
\hline Controls (as in Table 8 & Yes & Yes & Yes & Yes & Yes & Yes & Yes & Yes & Yes & Yes & Yes & Yes \\
\hline Industry and year dummies & Yes & Yes & Yes & Yes & Yes & Yes & Yes & Yes & Yes & Yes & Yes & Yes \\
\hline Constant & $\begin{array}{c}0.089 \\
(0.001)\end{array}$ & $\begin{array}{c}0.091 \\
(0.001)\end{array}$ & $\begin{array}{c}0.096 \\
(0.000)\end{array}$ & $\begin{array}{c}0.099 \\
(0.000)\end{array}$ & $\begin{array}{c}0.138 \\
(0.000)\end{array}$ & $\begin{array}{c}0.141 \\
(0.000)\end{array}$ & $\begin{array}{c}0.095 \\
(0.000)\end{array}$ & $\begin{array}{c}0.096 \\
(0.000)\end{array}$ & $\begin{array}{l}-0.129 \\
(0.007)\end{array}$ & $\begin{array}{l}-0.120 \\
(0.012)\end{array}$ & $\begin{array}{l}-0.036 \\
(0.617)\end{array}$ & $\begin{array}{l}-0.014 \\
(0.850)\end{array}$ \\
\hline$N$ & 15393 & 15393 & 15383 & 15383 & 14872 & 14872 & 14291 & 14291 & 15353 & 15353 & 13802 & 13802 \\
\hline Adjusted $R^{2}$ & 0.033 & 0.033 & 0.046 & 0.046 & 0.028 & 0.028 & 0.023 & 0.023 & 0.031 & 0.031 & 0.038 & 0.038 \\
\hline
\end{tabular}

Notes: This table presents the coefficients and p-values (in parentheses) using the 2SLS regressions with HAC standard errors. Firm growth is the log-difference of net sales for company $i$ from country $c$ between time $t$ and $t-1$. Family is the dummy variable that equals one if 1 if the founder or descendant or family member is director or large shareholder, zero otherwise. WGI $\mathrm{W}_{\mathrm{c}}$ is the mean-centered WGI index. Industry concentration is the sum of squared market shares using segment sales at the industry level. Innovation output is the brands and patents-to-net-sales ratio. Public spending is cash payments for operating activities of the government in providing goods and services (this includes compensation of employees, interest and subsidies, grants, social benefits, and expenses such as rent and dividends). Internationalization is the ratio between foreign sales and net sales. Population size is the logarithm of country's population. Control variables are the following: Firm size, Cash flow, R\&D, Firm age, Leverage, GDP growth, Inflation and Trade. All the definitions of control variables are provided in the Data section. Endogenous variables are the following: Firm size, R\&D and Cash flow. Instrumental variables are the following: the second-year lagged values of Firm size and R\&D, and both the first- and the second-year lagged values of Cash flow. 